Original paper

\title{
Stratigraphy, structure and geology of Late Miocene Verkhneavachinskaya caldera with basaltic-andesitic ignimbrites at Eastern Kamchatka
}

\author{
Olga BERGAL-KUVIKAS 1,2,3*, Vladimir LEONOV ${ }^{1 \dagger}$, Aleksei ROGOZIN¹, Ilya BINDEMAN ${ }^{3,4}$, \\ Evgeniy KLIAPITSKIY' ${ }^{1}$, Tatiana CHURIKOVA ${ }^{1,5}$
}

\author{
${ }^{1}$ Institute of Volcanology and Seismology, Far East Branch, Russian Academy of Science, Piip Boulevard 9, \\ Petropavlovsk-Kamchatsky,683006,Russia; olgakuvikas@gmail.com \\ ${ }^{2}$ Institute of Geology of Ore Deposits, Petrography, Mineralogy and Geochemistry, Staromonetnyi per. 35, Moscow, 119017, Russia \\ ${ }^{3}$ Fersman Mineralogical Museum, Leninskii avenue 18 build. 2, Moscow, 115162, Russia \\ ${ }^{4}$ Department of Earth Sciences, 1272 University of Oregon, Eugene, OR 97403, USA \\ ${ }^{5}$ Geowissenschaftliches Zentrum Göttingen, Abteilung Geochemie, Universität Göttingen, Goldschmidtstraße 1 build. 2408 , \\ Göttingen, 37077, Germany \\ ${ }^{*}$ Corresponding author \\ + Deceased
}

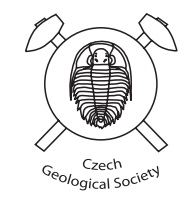

\begin{abstract}
We describe a new caldera-volcano in the volcanic front of Kamchatka named Verkhneavachinskaya caldera (VC). According to geological mapping, the VC is interpreted as an eroded shield volcano with a summit caldera exposing $1 \mathrm{~km}$-thick lava-like ignimbrites. It is one of the largest $(10 \times 12 \mathrm{~km}$ diameter) and oldest (c. 5.78-5.58 Ma, Ar-Ar dating) morphologically preserved paleovolcano in Kamchatka. The welded ignimbrites with fiammes are andesites-basaltic andesites in composition, they are more mafic than most ignimbrites worldwide and than other post-Pliocene calderas in Kamchatka. The deposits of VC are interbedded layers of welded ignimbrites and volcanoclastic material, which we interpret as result of long-lived volcanic center activity with hot pyroclastic flows and subsequent accumulations of volcanoclastic suites (e.g. lahars). The most trace element ratios in $\mathrm{VC}$ rocks (e.g. La/Yb, Nb/La, Ba/Th) show similarity with post-accretion magmatism at Kamchatka and especially with Late Pleistocene-Holocene Bakening volcano located in the same area. The VC provides new insights into the early stages of Kamchatka frontal zone development after the Kronotsky Arc Terrane accretion. This potentially explains the origin of voluminous basaltic-andesitic ignimbrites formed on thin crust during the initial stage of the arc formation.
\end{abstract}

Keywords: Kamchatka, Verkhneavachinskaya caldera, mafic ignimbrites, welded ignimbrites Received: 3 January 2019; accepted: 24 January 2020; handling editor: V Rapprich

\section{Introduction}

The Kamchatka Arc is a "land of calderas" with the largest number of collapse calderas per unit of arc length on Earth (Hughes and Mahood 2008; Bindeman et al. 2010). It is thus obvious that studies of products of pyroclastic and caldera-forming eruptions are important for volcanic hazard mitigation and for learning about the caldera collapse mechanisms. Worldwide, the majority of volcanoes and calderas produce ignimbrites with silicic compositions; only a few morphologically-expressed calderas with ignimbrites of more mafic composition are known from some island arcs. It is more common that basic-intermediate compositions are present as a minor component within deposits of silicic calderas (Global Volcanism Program 2013) but not as an independent and dominant eruptive material leading to caldera formation.

This paper deals with a newly described Verkhneavachinskaya caldera (VC; Leonov et al. 2011). This means 'upper Avachan', because of it is location upstream of the Levaya Avacha river (Figs 1-2). The VC is predominantly mafic, without significant known felsic counterparts. Such unusual calderas with basaltic andesite-andesitic magma compositions are rare globally and thus their origin is still poorly understood. The main topic of the present research is to describe the nature and understand processes of formation of such unusual basaltic-andesitic ignimbrites. They clearly require a particular geological setting in continental arcs worldwide, including Kamchatka.

Summarizing the previous studies of the VC, no researchers have correctly identified ignimbrite-like deposits as caldera deposits or, at least, as an important Pliocene magmatic center. Furthermore, the compositions of these deposits were not well characterized. In this paper we define a single large eroded volcanic structure named as Verkhneavachinskaya caldera (VC). 
The main goals of the present paper are the field identification of types of the volcanogenic deposits, determination of ignimbrites areal distribution and assessing geological conditions required for genesis of ignimbrites with basaltic andesite-andesitic composition.

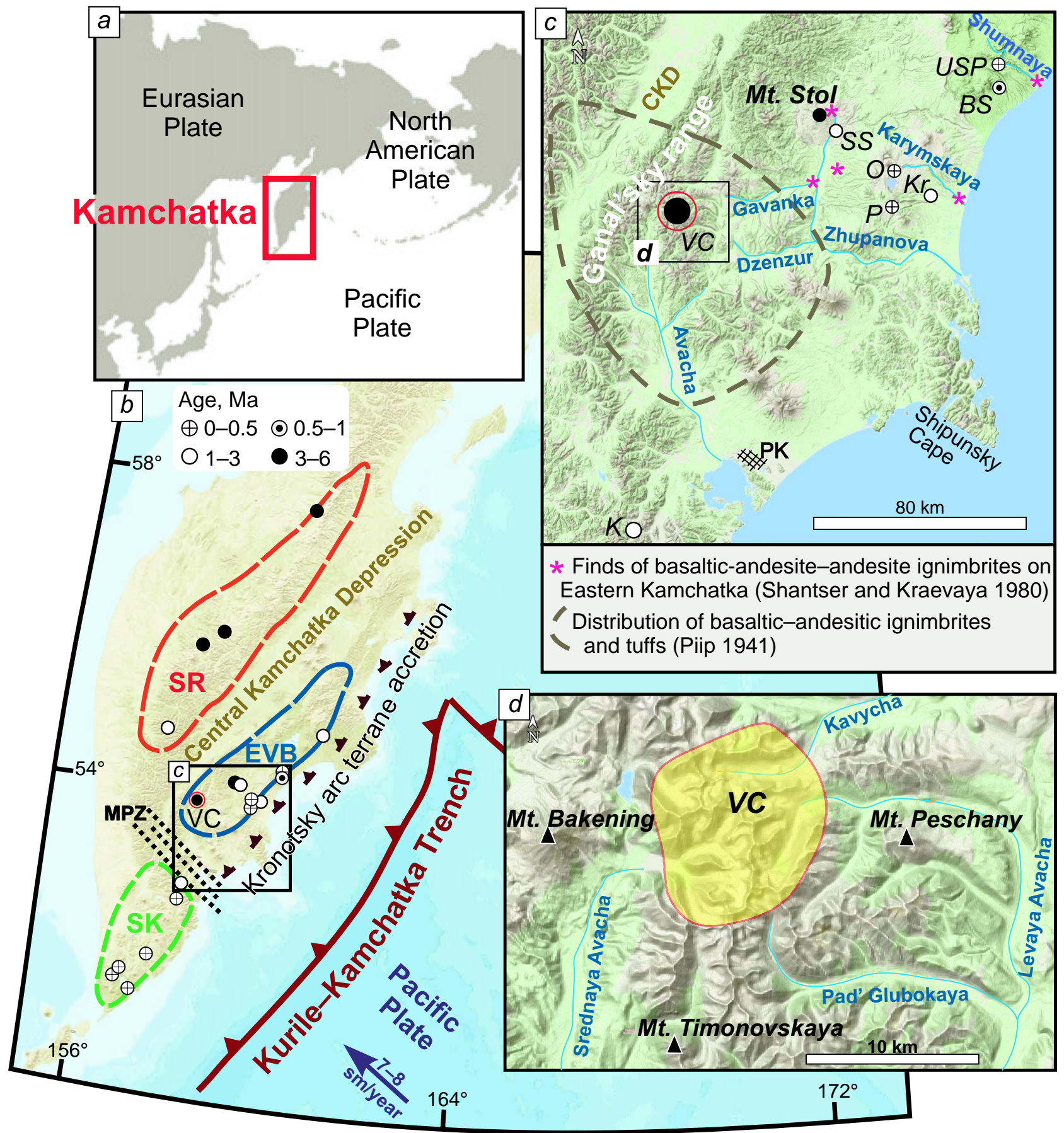

Fig. 1 The present-day geodynamic setting of the Kamchatka Peninsula. Position in the western Pacific (a) and the local tectonic configuration showing large pre-Holocene calderas (b) with ages from Bindeman et al. (2010). Abbreviations: EVB - Eastern Volcanic Belt, CKD - Central Kamchatka Depression, SK - Southern Kamchatka, SR - Sredinny Range, MPZ - Malko-Petropavlovsk Zone of dislocations, PK - city of Petropavlovsk-Kamchatsky. Position of Kronotsky Arc Terrane accretion is shown according to Lander and Shapiro (2007). c-d - Southern part of EVB with location of the Verkhneavachinskaya Caldera (VC) and findings of basaltic-andesitic ignimbrites. Abbreviations of large caldera-forming eruptions according to Bindeman et al. (2010): USP - Uzon-Shorokoe Plateau, BS - Bolshoy Semyachik, SS - Stena-Soboliny, $\mathrm{O}$ - Odnoboky, Kr - Korneva river ignimbrites, P - Polovinka, K - Karymshina caldera. Boundary of intra-caldera deposits of VC, studied in this paper, is also shown. 


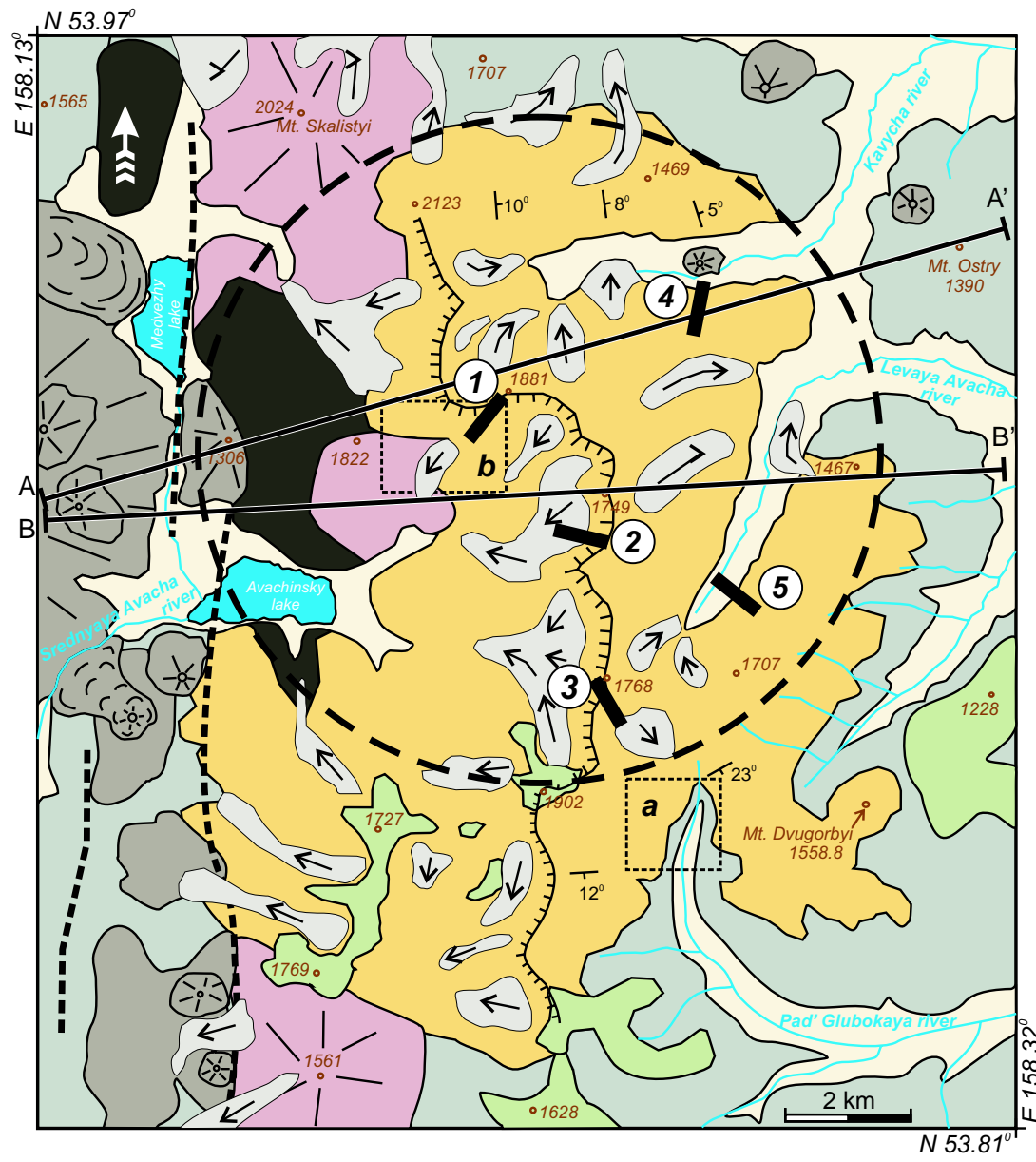

\section{Post-caldera stage}

(2) Pleistocene cinder cones and related lava flows

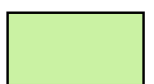

P liocene-early Pleistocene andesitic lava flows

Late Miocene diorite intrusions

\section{Caldera stage}

Late Miocene ignimbrites and volcaniclastic deposits

\section{Pre-caldera stage}


Alluvium, glacial and debris deposits, arrows indicate movement of land-slides. Late Pleistocene-Holocene

Cliffs of Avachinsky range

Faults that bound the Srednyaya Avacha river graben
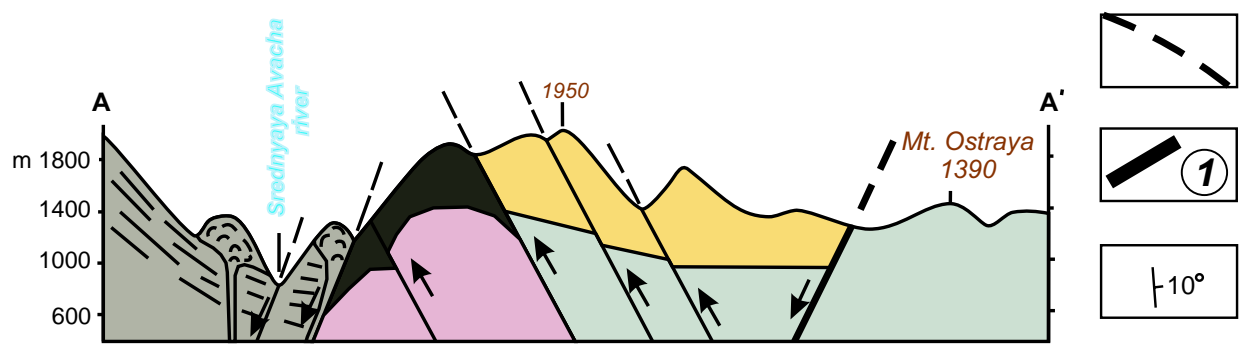

Boundary of VC

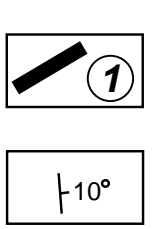

Location of studied outcrops

(1 - L-2010, 2 - L-2014

3 - L- 2012, 4- R-2009,

5 - L-2009)

Dips of the ignimbrite layers

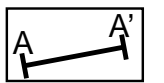

Locations of

geological profiles


Contacts of caldera-forming deposits with pre-caldera (a) and post-caldera (b) formations

Tectonic boundary of VC

Intracaldera blocks

Fig. 2 Schematic map and geological profiles of VC intra-caldera deposits (a) in the headwaters of the Levaya Avacha and Kavycha rivers, and cross sections (b-c). Contacts of intra-caldera deposits with pre-caldera and post-caldera stage deposits are illustrated in a greater detail in Figs 7-8. Geologic map modified from Leonov et al. (2011). 


\section{Geological setting}

\subsection{General tectonic framework}

The Kamchatka Arc is located at the northeastern convergent boundary of the Eurasian and Pacific plates, below which the Pacific Plate has been subducting at the convergence rate of $\sim 9 \mathrm{~cm} /$ year for the past 10-20 Ma at least based on reconstructed trajectories of Pacific islands (Geist and Scholl 1994).

Assembly of Kamchatka took place via sequential accretion of fragments and possibly a subduction polarity switch in Eocene ( 54 Ma, Hourigan et al. 2009; Konstantinovskaya 2011). It was followed by an accretion of the Kronotsky Arc Terrane proceeding from south (Shipunsky cape, $7 \mathrm{Ma}$ ) to north (e.g. Kronotsky cape, 5 Ma and Kamchatsky cape, 2 Ma). Initially, this accretion with Kamchatka caused the Late Eocene extinction of the northern part of the older subduction zone. It was followed by a subduction jump, and formation of the present subduction zone $c .150$ km eastwards. New subduction zone was initiated at $c$. $7 \mathrm{Ma}$ ago and gradually expanded northwards during at least $5 \mathrm{Myr}$ (Lander and Shapiro 2007) (Fig. 1). The hypothesis assuming slab jumping and ensuing trench migration has been supported by geochemical and isotopic data of Volynets (1994) and Avdeiko et al. (2007). Finding diachronous (since 12 Ma till Holocene) Nb-enriched basalts with adakitic signatures was interpreted as reflecting the slab jump and formation of slab window during Kronotsky Arc Terrane accretion (Avdeiko and Bergal-Kuvikas 2015).

\subsection{Eastern Volcanic belt (EVB)}

The modern volcanism of Kamchatka is concentrated in three zones parallel to the trench. These are, from east to west: Eastern Volcanic belt (EVB), the Central Kamchatka Depression (CKD), and the Sredinny Range (SR) (Fig. 1). Chemical compositions show systematic variations from the volcanic arc front (Komarovsky volcano) to the back-arc (Ichinsky volcano) and indicate the involvement of distinct sources (Churikova et al. 2001).

The basement of EVB is built by deposits of continental slope, including siliceous-volcanogenic deposits with chert intercalations among pillow basalts. According to their radiolarian assemblage, these cherts were dated as Campanian (72-83 Ma) (Levina et al. 1983; Savelyev et al. 2005). Basaltic lava fields were found in the basement of EVB upstream of the Levaya Zhupanova river and on the Tumrok Mt. (Shantser and Kraevaya 1980) (Fig. 3). According to Ar-Ar dating of basalts from the Levaya Zhupanova river, the primary subduction magmas in EVB were formed in Mid-Late Miocene (7-12 Ma). These basalts are characterized by strongly enriched OIB-like compositions with enriched mantle plume (EM1) isotopic contents (Hoernle et al. 2009). Volynets et al. (1997) proposed a two-component mixing model for the generation of Miocene subduction magmas under the EVB. The $\mathrm{Sr}-\mathrm{Nd}-\mathrm{Pb}$ and $\mathrm{O}$ isotopic data provide further evidence that the sources of the Late Cenozoic volcanism of the within-plate and islandarc geochemical types were different. Differences in mantle wedge produced melting of the enriched mantle (EM1 type) in Middle Miocene. Later, magmatism tapped the peridotite mantle wedge (N-MORB type) due to slab's dehydration since Late Miocene to PlioceneQuaternary times (Volynets et al. 1997).

\subsection{Verkhneavachinskaya caldera}

The Verkhneavachinskaya caldera (VC) is located in EVB, $105 \mathrm{~km}$ NW of the capital city PetropavlovskKamchatsky (Fig. 1). The investigated area belongs to the springheads of the Levaya Avacha and Kavycha rivers (Fig. 2) forming a horst called Avachinsky Range, which extends $20-25 \mathrm{~km}$ from north to south. High rates of uplift (at least $1.5 \mathrm{~km}$ since its formation at 5.5 Ma: Nikolaev 1977) and erosion were responsible for a quick uplift and exposure of thick intra-caldera sections and made this area accessible to detailed geological studies.

The ignimbrite fields with exclusively basic-intermediate compositions in the VC area of Kamchatka were studied previously by several researchers. Von Ditmar (1901) was the first who described conglomerates of trachytic rocks in basement of the largest watershed of Kamchatka, in upper streams of Avacha, Bustraya and Kamchatka rivers. Bogdanovich (1904) examined areas covered by voluminous pyroclastic and volcaniclastic materials and suggested their connection to the older large monogenic (single collapse) calderas. Others were ascribed to later (Holocene) Bakening, Avachinsky and Kozelsky polygenic stratovolcanoes that formed on the rim of caldera. Piip (1941) thought that these Holocene volcanoes belonged to arc-perpendicular linear zones. Origin of andesitic pyroclastic deposits upstream of Avacha river was correlated with voluminous fissure eruptions. Shantser and Kraevaya (1980) described a large tectonic-magmatic depression located in upper stream section of the Avacha and Kavycha rivers. However, in later publications, the existence of depression was not confirmed. Aliskerov (1980), based on the similarity of ore deposits and pyroclastic rocks, identified the Avachinsko-Ketkoysky uplift zone. According to the geological map of Eastern Kamchatka, Sheimovich and Markovsky (2000) linked the genesis of ignimbrites to a single strong explosion with simultaneous magma chamber collapse. Using locations of faults, Egorov (2009) determined the 
Avachinsky-Ganalsky center of subaerial mafic volcanism.

Our field work along the Levaya Avacha and Kavycha rivers commenced in 2009. First results of geological studies and whole-rock chemistry were presented by Kuvikas and Rogozin (2009), Rogozin and Kliapitskiy (2010), Leonov et al. (2011) and Kliapitskiy (2014). Dating of ignimbrites, determination of the paleovolcano type as a caldera and calculations of erupted materials volume were given by Leonov et al. (2011). Preliminary comparative analysis of geochemical composition of VC with other Kamchatkan calderas was published by Rogozin et al. (2011). Based on stratigraphical positions of the layers, some of the ignimbrites were correlated with each other (Bergal-Kuvikas et al. 2016a). The main results of the VC study were presented on a conference by BergalKuvikas et al. (2016b).

In this article we use the term paleovolcano according to definition by Aprelkov et al. (2005). In active arcs, such as Kamchatka, the pyroclastic deposits of paleovolcanoes (1) are strongly eroded, (2) show displacements due to active seismicity, (3) are covered by Holocene rocks, (4) preserved deposits represent only fragments of pyroclastic rocks on flat plateaus and (5) most of them show hydrothermal activity (Aprelkov et al. 2005).

According to geological mapping by Kamchatka Geological Survey in

Fig. 3 Outcrops in the headwaters of the Levaya Avacha and Kavycha rivers taken from helicopter. Locations of presented outcrops are shown on Fig. 2. Layers numbers on photos and types of the rocks correspond to same sample numbers as in Fig. 4. Photos illustrate eroded sections of volcano-sedimentary deposits with interbedded layers of ignimbrites and volcaniclastic deposits. Continuous, rigid layers are probably massive, volatile-enriched pyroclastic flows that could have travelled far. Whitish layers are volcaniclastic deposits that are mainly concentrated between ignimbrites. Dips of the sub-horizontal bedding of layers are less than $8^{\circ}$. This possibly means that the layers were formed on shield volcano with flat slopes.
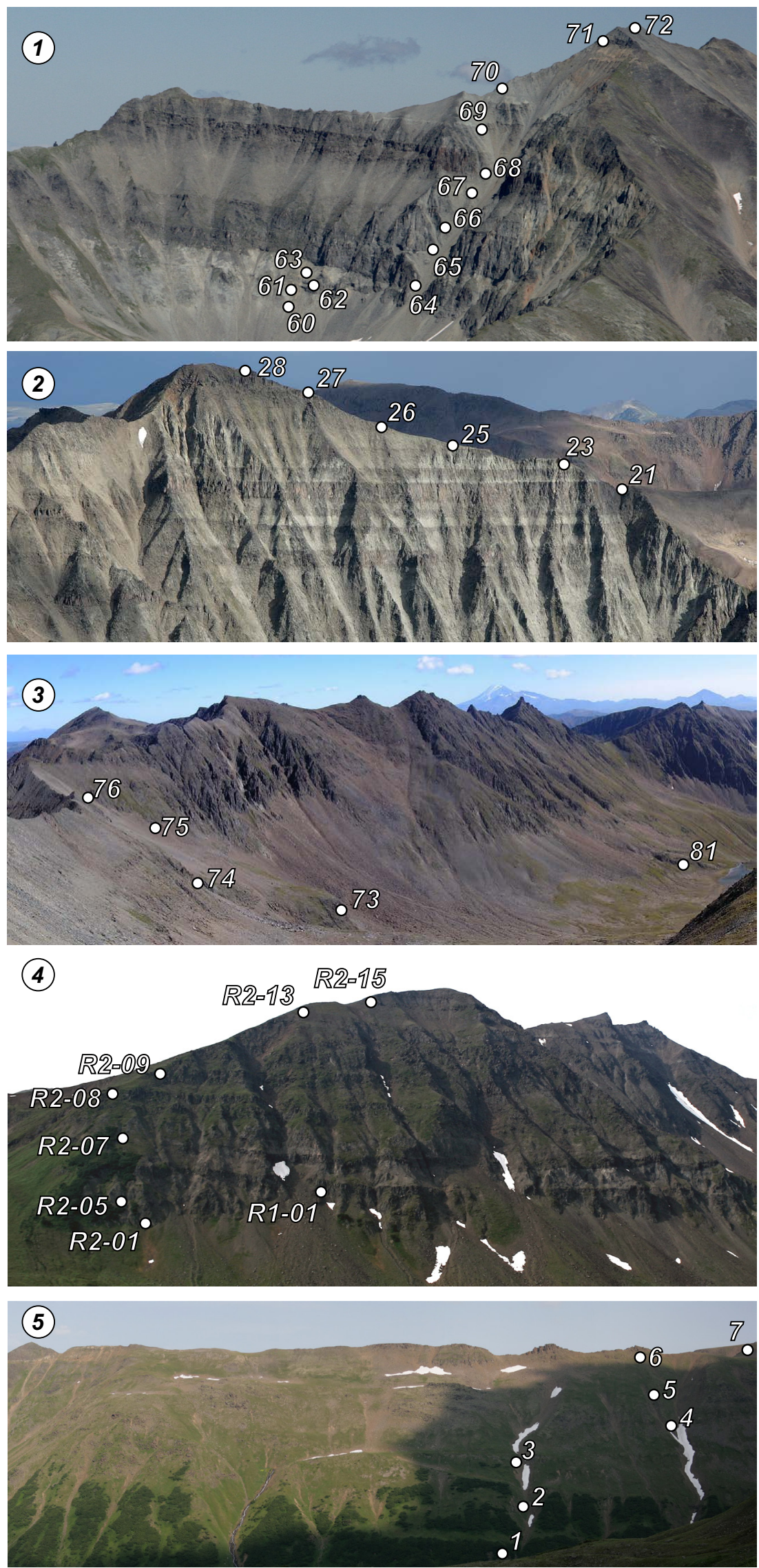


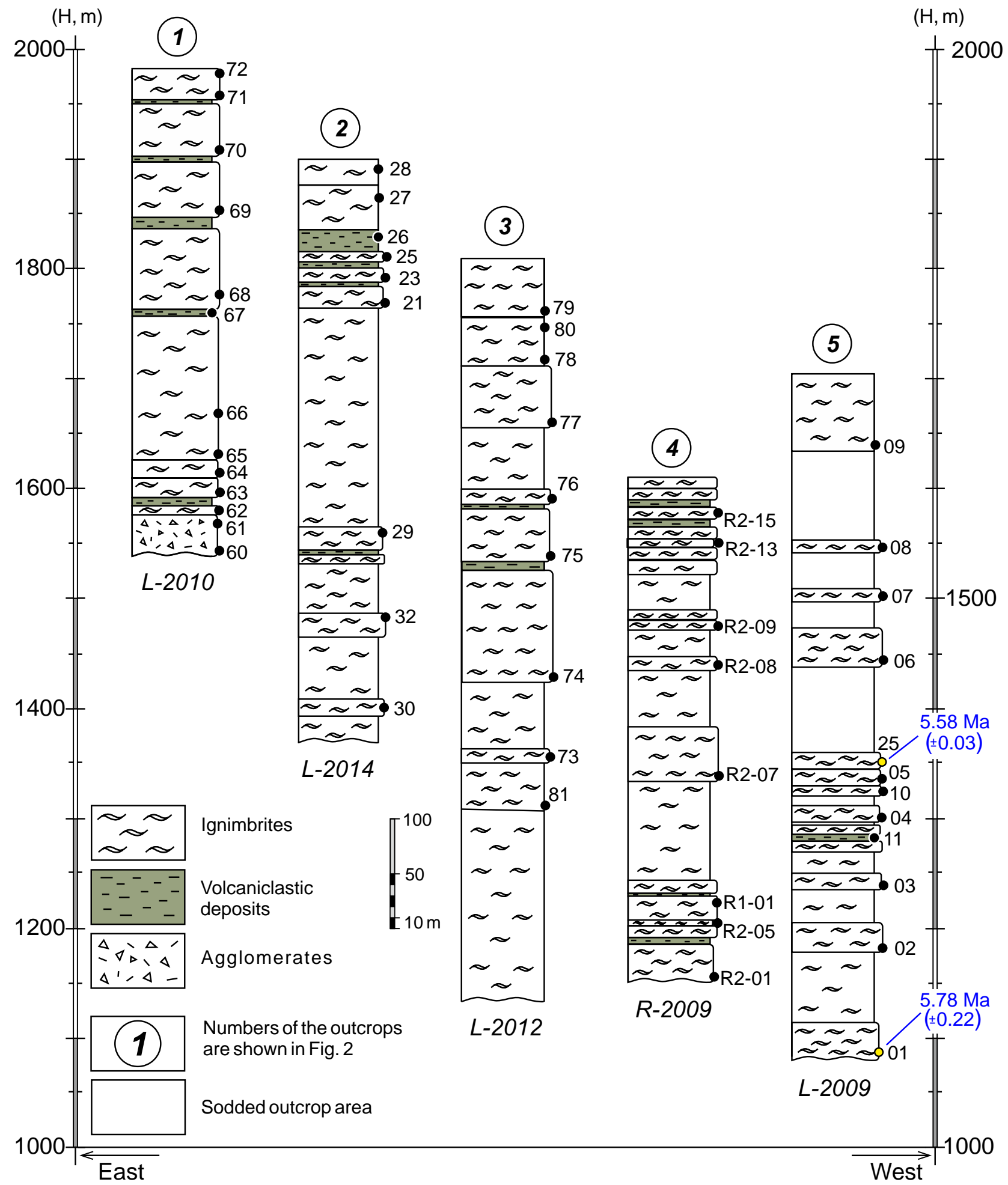

Fig. 4 Stratigraphic sections of outcrops (see Fig. 2 for their locations Fig. 3 for their photos).

2000s (Boyarinova et al. 2006), Late Miocene ignimbrites are widely distributed throughout the investigated area (Figs 2-5) around VC. Additionally, the porphyritic basalts and agglomerate tuffs (Fig. 2) were found in the basement. These rocks rest directly on Late Cretaceous siltstones and argillites (Shantser and Kraevaya 1980; Sheimovich and Markovsky 2000) and thus may record, at least locally, initiation of the volcanic activity since 

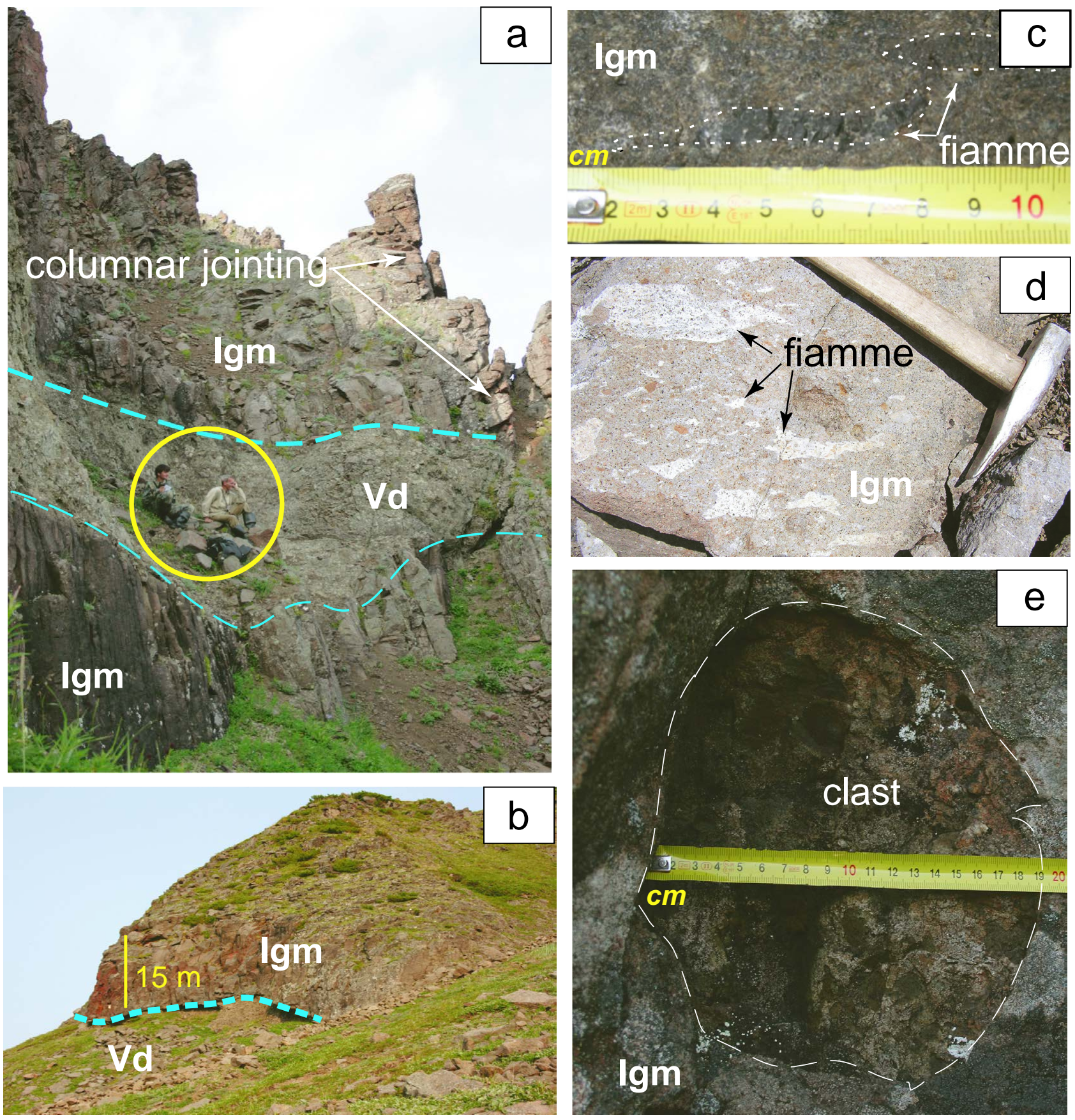

Fig. 5 Field exposures of ignimbrites. a-b Lange-scale view showing columnar jointing in ignimbrites and contacts with volcaniclastic deposits, two persons for a scale. $\mathbf{c}$ - Black fiamme. $\mathbf{d}$ - White fiamme. e-Vesicular clast of basaltic-andesitic composition in ignimbrite. Abbreviations: Igm - ignimbrites, Vd - volcaniclastic deposits.

accretion of the Kronotsky Arc Terrane at 7 Ma ago (Lander and Shapiro 2007). Complicating the local structure on the west side, there is a horst transition into an arc-perpendicular graben of the Avacha river. Quaternary Bakening and Zavaritsky volcanoes and numerous areal cinder cones belong to this graben (Fig. 6). The throws of boundary faults surrounding this graben are estimated at several hundreds of meters (Legler 1976).

\section{Samples and analytical methods}

\subsection{Sampling}

In order to study the origin of recently recognized massive ( $>500$ meters thickness) pyroclastic deposits upstream of the Avacha and Kavycha rivers, we conducted fieldwork in 2009-2012 and 2014, and an additional he- 

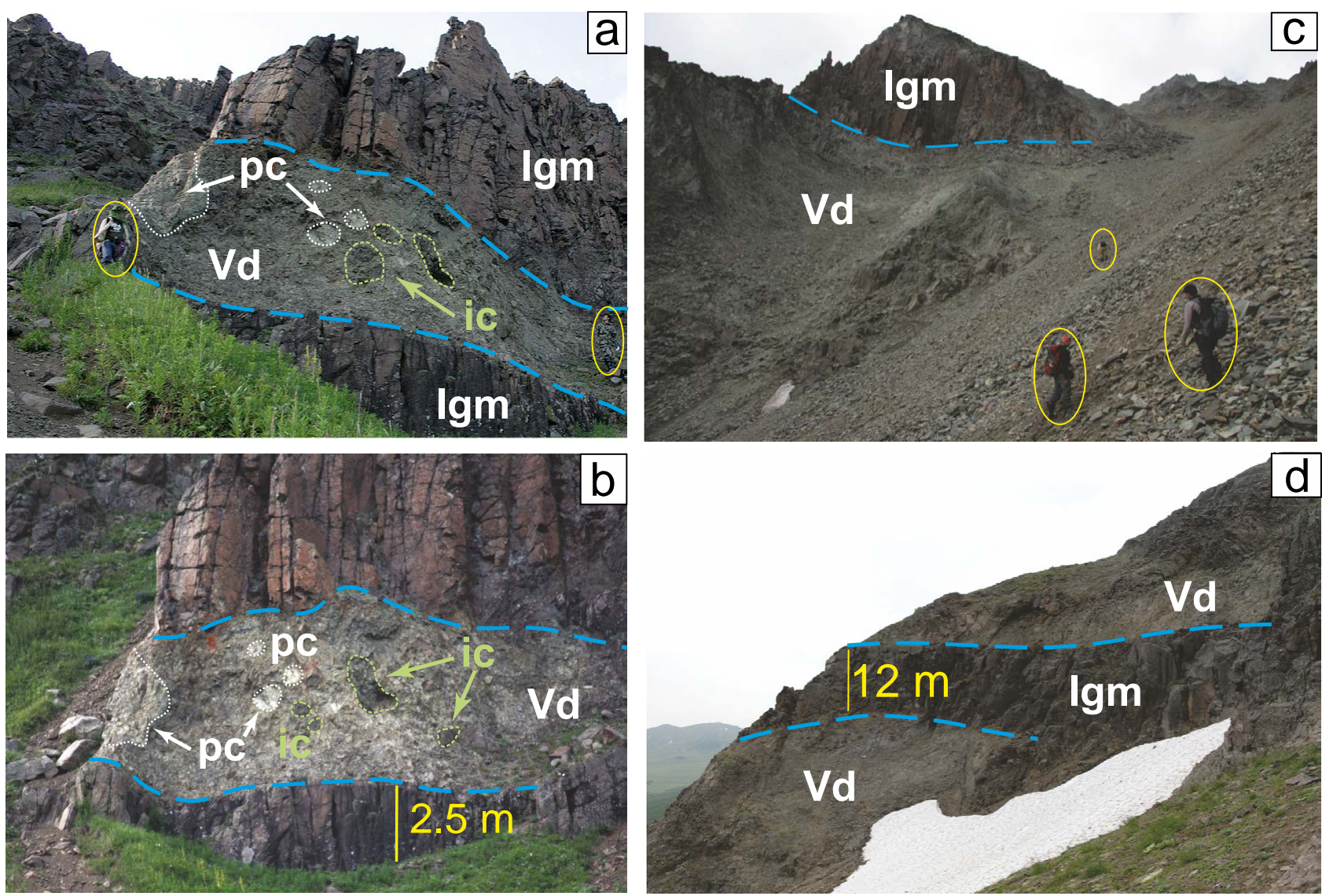

Fig. 6 Outcrops of volcaniclastic deposits. Location is shown on Figs 3-4. a-b Outcrops that contain white pieces (white dotted lines) and dark dense ignimbrites clasts (green dotted lines). Section 4 (L-2009), documentation point 11 (altitude 1309 m). c - Outcrop with altered tuffs lacking clasts inside the layers. Section L-2010, a layer below the documentation point 69 (altitude $1833 \mathrm{~m}$ ). d - Outcrop with altered tuffs lacking clasts inside the layers. Section R-2009, documentation point R1-01 (altitude $1221 \mathrm{~m}$ ). Abbreviations: Igm - ignimbrites, Vd - volcaniclastic deposits, pc - pumice clasts, ic - ignimbrite clasts.

licopter reconnaissance flight in 2019. The area has no accessible roads and fieldwork is challenging partly due to dense vegetation. Active uplift and erosion produced incised river valleys that enabled us to observe deep sections of many natural outcrops in the field. Using satellite images and geological maps, and observations from the helicopter, we chose five representative outcrops located in different parts of the investigated area (Figs 2-4). We noted the positions and altitude of sampling points using GPS, and described the rock types. Using these descriptions and additional observations of ridges and satellite photos, we correlated the sections and made detailed geological maps of the area $(20 \times 20 \mathrm{~km})$ focusing on eruptive history and emplacement mechanism. Annual field works during five years enabled us to obtain a representative rock collection, study the contacts between the different geological suites, discover the presence of large volumes of ignimbrites and define their precise areal distribution. We documented stratigraphic relations of the deposits, lithological facies and included their photographs. To avoid influence of contact alterations between the faces we collected samples from inner parts of the layers. Most attention was spent to select samples without clasts. The sample locations are shown in Figs 2 and 4.

\subsection{Whole-rock geochemistry}

Major- and trace-element contents of whole rocks were analyzed at Geoscience Centre (GZG), Göttingen University. In order to minimize contamination during the crushing, we used an agate pounder. We analyzed glassy homogenous rock fragments from black and dense ignimbrite layers. Major and some trace elements (Sc, V, Cr, Co, Ni, Zn, Ga, Sr, Zr, Ba) in 24 samples were determined by standard X-ray fluorescence (XRF) analysis on glass discs prepared with a sodium tetraborate flux. International standards (BCR 1, BE-N) were analyzed together with unknown samples. Analytical errors for major elements are less than $1 \%$, for trace elements around $5 \%$, and for loss on ignition (LOI) better than $7.2 \%$. 


\subsection{Age dating}

The ${ }^{40} \mathrm{Ar} /{ }^{39} \mathrm{Ar}$ dating of groundmass in the ignimbrite samples was performed at the University of WisconsinMadison Rare Gas Geochronology Lab (B. Jicha, analyst) under the framework of a joint project for the study of large-volume caldera-forming eruptions in Kamchatka (Bindeman et al. 2010, 2019). In order to estimate the age of early stage of caldera-forming eruptions we analyzed the lowermost ignimbrite layers (01L-2009, 25L-2009) in outcrops (Fig. 3).

Only a few zircons could have been separated from the same samples and dated by $\mathrm{U}-\mathrm{Pb}$ method using the Cameca 1270 ion microprobe at Standford University.

The details of Ar-Ar dating of groundmass of ignimbrites and $\mathrm{U}-\mathrm{Pb}$ dating of zircons are described in Bindeman et al. (2010, 2016).

\section{Results}

\subsection{Stratigraphy and characteristics of pyroclastic deposits and volcaniclastic deposits}

Structural differences, colors and contents of the volcaniclastic deposits enable us to distinguish two main lithofacies occurring on the observed natural outcrops (Figs 5-6). Because the observed layers from both lithofacies are interbedded, the two facies clearly coexisted, were both equally widespread and eroded/uplifted together. We can identify two facies based on the same characteristics of their formation and deposition mechanism (Tab. 1).
The first lithofacies includes pyroclastic rocks, in which fragments were produced by explosive fragmentation (Fig. 5). Black, dense, massive lava-like ignimbrite layers dominate the VC pyroclastic rocks. Columnar jointing occurs in most of the observed layers. The columns are typically perpendicular to the contacts with lower layer (Fig. 5a-b). The thickness of individual layers reaches up to several tens of meters. Some ignimbrite layers contain black glassy fiamme (Fig. 5c), others white ones. Sizes of identified fiamme range from few to few tens of centimeters (Fig. 5c-d). The clasts of $15-20 \mathrm{~cm}$ in diameter are poorly sorted and distributed chaotically with no obvious grading within individual beds. The clasts represent fragmented blocks of surrounding ignimbrites (Fig. 5e). In this work we define basaltic andesite-andesite ignimbrites (with 56 wt. \% $\mathrm{SiO}_{2}$ ), as deposits that have several of the characteristic features. In the field they are typically looking as welded ignimbrite sheets forming colonnades each consisting of chaotic pumices, scoria and fiamme. Such an appearance distinguishes them from much more typical basaltic lavas of any kind: agglomerate, agglutinated, and plateau-type.

The second common lithofacies is represented by chaotic volcaniclastic deposits (Fig. 6) that were produced by weathering and erosion of solidified/lithified volcanic rocks of any types (Fisher 1961; McPhie et al. 1993). In the VC occur yellow-orange, reworked, altered coarse crystal-rich volcaniclastic deposits. They contain variously sized, rounded clasts of welded pumices and ignimbrites enclosed in a finer groundmass. Thickness of these layers, interbedded between ignimbrite layers, vary from few to tens of meters (Fig. 6). Matrix of the layers in the lowermost sections is massive and contains less than $3-5 \%$ of clays with more than $25 \%$ of rounded

Tab. 1 Specific characteristics of the two main lithofacies of the VC

\begin{tabular}{|c|c|c|c|}
\hline \multirow{2}{*}{\multicolumn{2}{|c|}{ Characteristics }} & \multicolumn{2}{|c|}{ Lithofacies } \\
\hline & & Pyroclastic (ignimbrites) & Volcaniclastic deposits \\
\hline \multirow[t]{3}{*}{ Field observations } & Visible macrostructures & $\begin{array}{l}\text { Columnar jointing, black densely welded } \\
\text { "lava-like” ignimbrite layers. Black, white } \\
\text { fiamme observed. }\end{array}$ & $\begin{array}{l}\text { White, yellow cemented, non-welded tuffs in } \\
\text { matrix with various clasts. }\end{array}$ \\
\hline & Thickness of layers & Vary from few meters to tens of meters & Vary from few meters to tens of meters \\
\hline & Lithology & Dense, same like ignimbrites & Pumice and ignimbrite clasts \\
\hline \multirow{3}{*}{ Clasts } & Sizes & $<0.5 \mathrm{~m}$ & $0.5-1.5 \mathrm{~m}$ \\
\hline & Geometries, forms & Rounded & Rounded \\
\hline & Distributions & Chaotic & Chaotic \\
\hline \multirow{7}{*}{$\begin{array}{l}\text { Microscope } \\
\text { observations }\end{array}$} & Sorting & Poor & Poor \\
\hline & Grading & Absent & Absent \\
\hline & Textures & Welded, hyalopilitic, eutaxitic & $\begin{array}{l}\text { Pyroclastic (mixture of ignimbrite fragments } \\
\text { and pumice with tuffs in matrix) }\end{array}$ \\
\hline & Phenocrysts & $\begin{array}{l}\text { Broken crystals of plagioclase, clinopyroxene } \\
\text { and olivine }\end{array}$ & Deformed, broken plagioclases crystals \\
\hline & Groundmass & Oriented plagioclase microcrystals, fiamme & Sulfide mineralization, quartz veinlets \\
\hline & Alteration & Low & Significant \\
\hline & Origin & Hot pyroclastic flows & $\begin{array}{l}\text { Fluvioglacial transportation of volcanogenic } \\
\text { material, e.g. in lahars }\end{array}$ \\
\hline
\end{tabular}



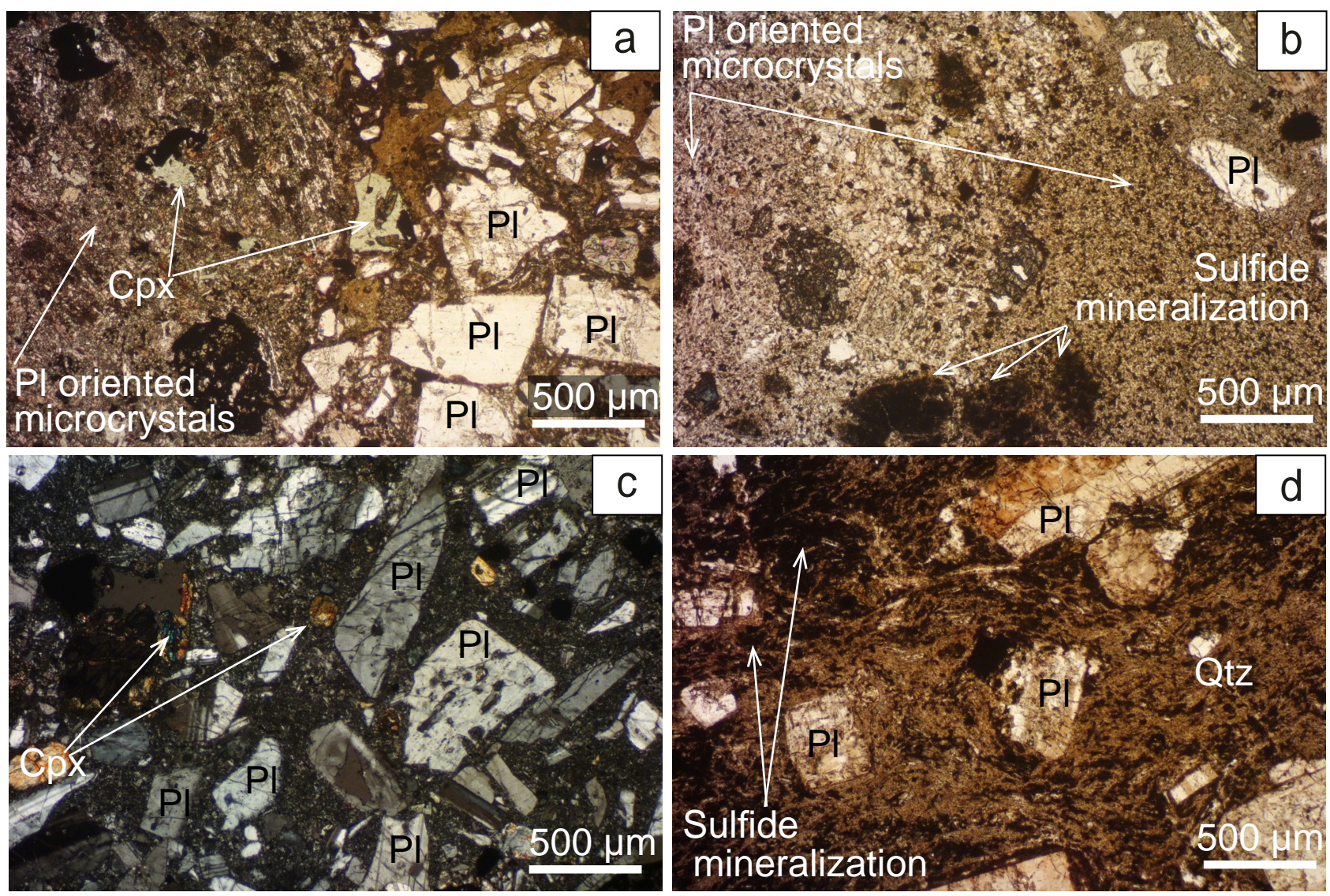

Fig. 7 Photomicrographs (a-b, d in plane-polarized light, c under crossed nicols) of the representative samples of pyroclastic rocks, correlated with ignimbrites on Fig. 4: L-2009-05 (a), L-2012-74 (b), and L-2012-76 (c). Sample L-2009-11 (d) is altered tuff with yellow-orange hue, shown on Fig. 4. Pl - plagioclase, Cpx - clinopyroxene, Qtz - quartz.

clasts. Clasts sizes range from 0.5 to $1.5 \mathrm{~m}$ (Fig. 6a-b). Other layers, mostly in upper parts of sections, are free of any larger clasts (Fig. 6c). The deposits are ill-sorted and non-graded. Distribution of these volcaniclastic deposits is rather irregular and counts of these layers vary among individual outcrops. Some of outcrops are significantly sodded, but at least one layer of volcaniclastic deposits occurs in section L-2012 and there are five in section L-2010 (Fig. 4).

\subsection{Petrography, dating and whole-rock chemistry}

The welded ignimbrites (e.g. L-2009-05, L-2012-74) contain broken, irregular plagioclase and clinopyroxene phenocrysts. Plagioclase phenocrysts reach up to 0.6 $\mathrm{mm}$, clinopyroxenes are $0.15-0.20 \mathrm{~mm}$ in diameter. The matrix contains oriented plagioclase microlites in a hyalopilitic texture (Fig. 7a-b). The shards of phenocrysts are deformed, stretched and compacted. The groundmass of crystal-rich volcanigenic deposits consists of deformed and irregular plagioclase crystals. These rocks are characterized by significant secondary hydrothermal alteration of the matrix with quartz veinlets. The alteration is accentuated also by sulfide mineralization of groundmass (Fig. 7b-d).

The ages of ignimbrites at the lower and middle parts of the observed intracaldera succession were determined by Ar-Ar dating to $5.78 \pm 0.22 \mathrm{Ma}$ (2009L-01) and $5.58 \pm 0.03$ Ma (2009L-25), respectively (Leonov et al. 2011; Fig. 4, Tab. 2).

The whole-rock major- and trace-element compositions (Tab. 3) show that ignimbrites vary from basaltic

Tab. $2{ }^{40} \mathrm{Ar} /{ }^{39} \mathrm{Ar}$ dating results for VC ignimbrites

\begin{tabular}{|c|c|c|c|c|c|c|c|c|c|c|c|c|}
\hline \multirow{2}{*}{$\begin{array}{l}\text { Sample } \\
\text { 25L-2009 }\end{array}$} & \multirow{2}{*}{$\begin{array}{c}\text { Material } \\
\text { groundmass }\end{array}$} & \multicolumn{2}{|c|}{$\begin{array}{c}\text { Total fusion } \\
\text { Age }(\mathrm{Ma}) \pm 2 \sigma\end{array}$} & $-\pi$ & \multicolumn{6}{|c|}{ Isochron } & \multicolumn{2}{|c|}{$\begin{array}{c}\text { Plateau } \\
\text { Age }(\mathrm{Ma}) \pm 2 \sigma\end{array}$} \\
\hline & & 5.48 & \pm 0.03 & 7 of 9 & 293.0 & \pm 3.2 & 5.60 & \pm 0.04 & 92.59 & 1.97 & 5.58 & \pm 0.03 \\
\hline 01L-2009 & groundmass & 6.03 & \pm 0.20 & 8 of 12 & 293.6 & \pm 2.3 & 6.23 & \pm 0.58 & 74.93 & 0.83 & 5.78 & \pm 0.22 \\
\hline
\end{tabular}

Note: J-value calculated relative to 28.201 Ma for the Fish Canyon sanidine (Kuiper et al. 2008) 

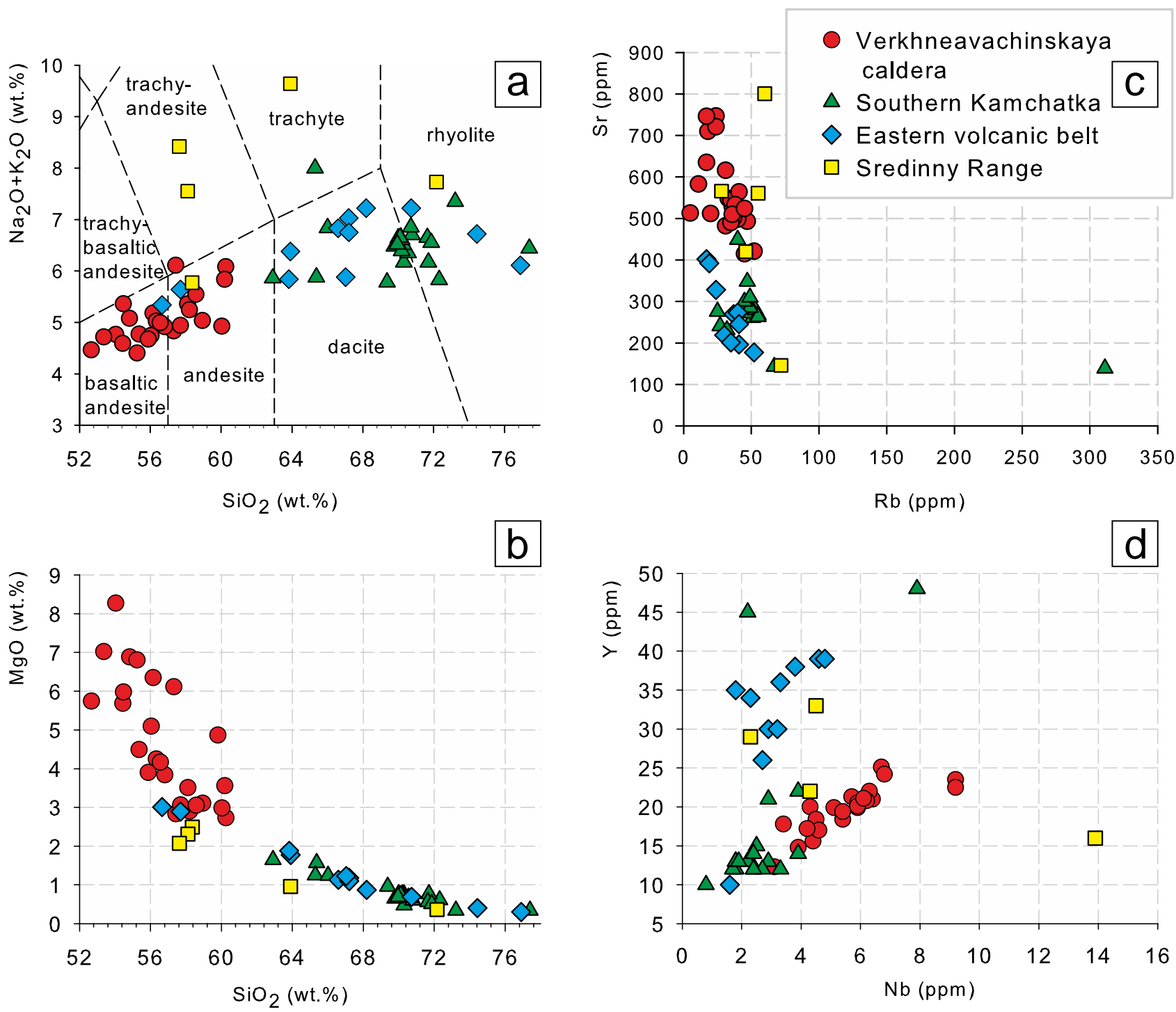

Fig. 8 Whole-rock major- and trace-element diagrams for the VC (Tab. 3) and other Kamchatkan calderas (Bindeman et al. 2010; see Fig. 1 for their locations). Total alkali-silica (TAS) classification is according to Le Maitre (2002).

andesite to andesite (Fig. 8a), with a marked decrease in $\mathrm{FeO}^{*}, \mathrm{CaO}, \mathrm{MgO}$, and $\mathrm{TiO}_{2}$ with rising silica (e.g., Fig. 8b). In comparison with other ignimbrite fields in Kamchatka, the rocks from VC are characterized by higher contents of MgO, $\mathrm{Nb}$ and $\mathrm{Sr}$ (Fig. 8c-d), as well as lower contents of $\mathrm{SiO}_{2}$ and alkalis (Fig. 8a). Thus the rocks from the newly discovered caldera have less siliceous and more magnesian compositions compared to products of other caldera-forming eruptions in Kamchatka.

\subsection{Spatial distribution of the ignimbrites, volcaniclastic deposits and delineation of eroded volcanic edifice}

The succession of pyroclastic deposits ( $>500$ meters of exposed total thickness) is distributed over a wide area of the Avachinsky Range (Fig. 2). Natural outcrops show interbedded layers of black dense ignimbrites (Fig. 5) and white-yellow volcanogenic sedimentary deposits (Fig. 6). The thicknesses of single layers range from 1-2 to 10-20 meters. Contacts between layers are sharp and well-defined. Volcaniclastic deposits are distributed very irregularly. Thicknesses of the rocks, and their variations in space enable us to distinguish intra- and extra-caldera deposits.

Pyroclastic rocks of intra-caldera succession cover an area c. $10-12 \mathrm{~km}$ across, and are more than $1 \mathrm{~km}$ thick based on outcrop observations and drilling of pyroclastic rocks near the Avachinsky lake, inside the boundary of volcano (Shantser and Kraevaya 1980). The ignimbrites compositionally similar to the VC were also found north of Mt. Skalistyi, in the south-eastern slopes of Mt. Dvugorbyi, and suggest that the extent of these rocks exceeds 


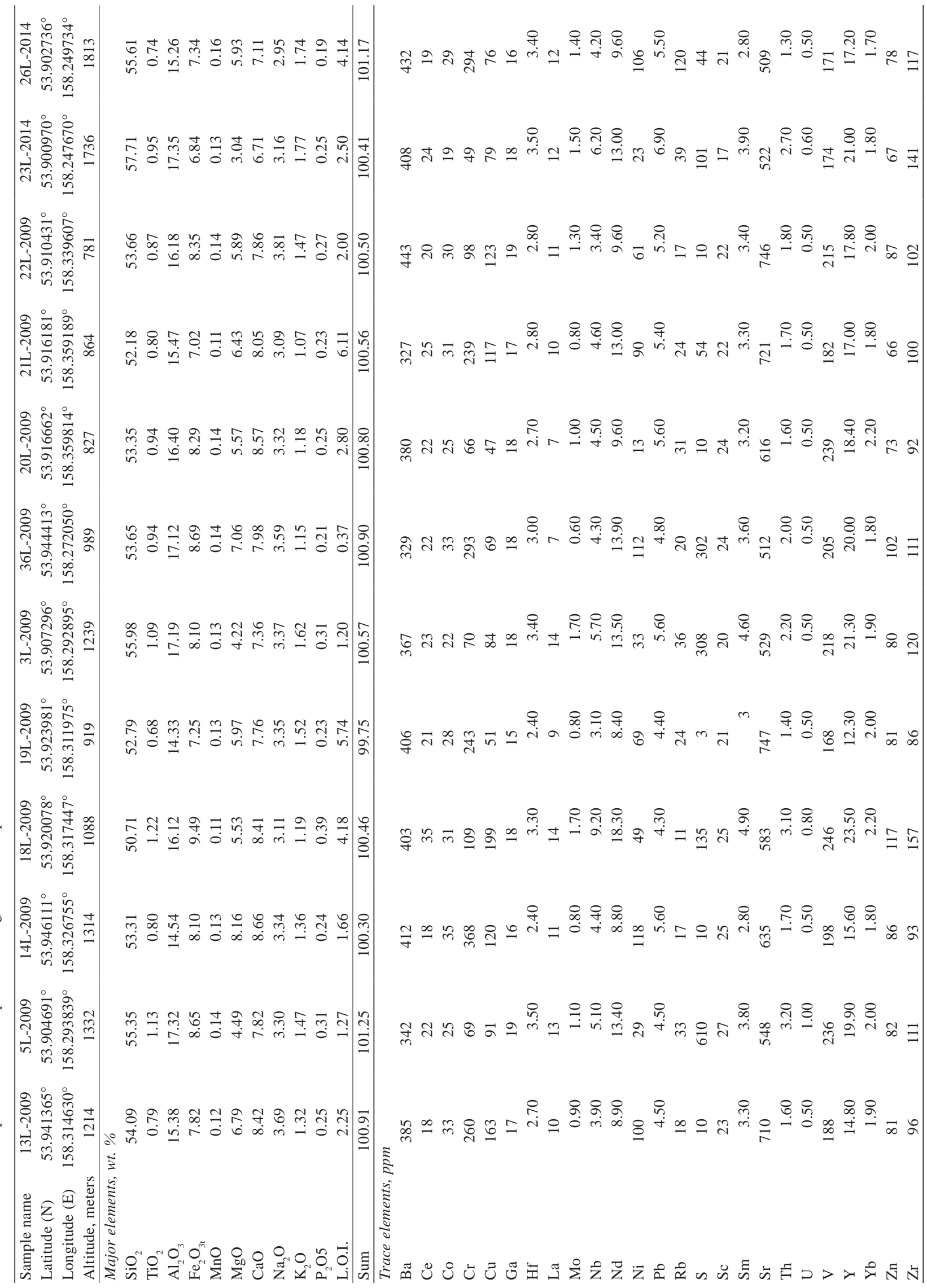




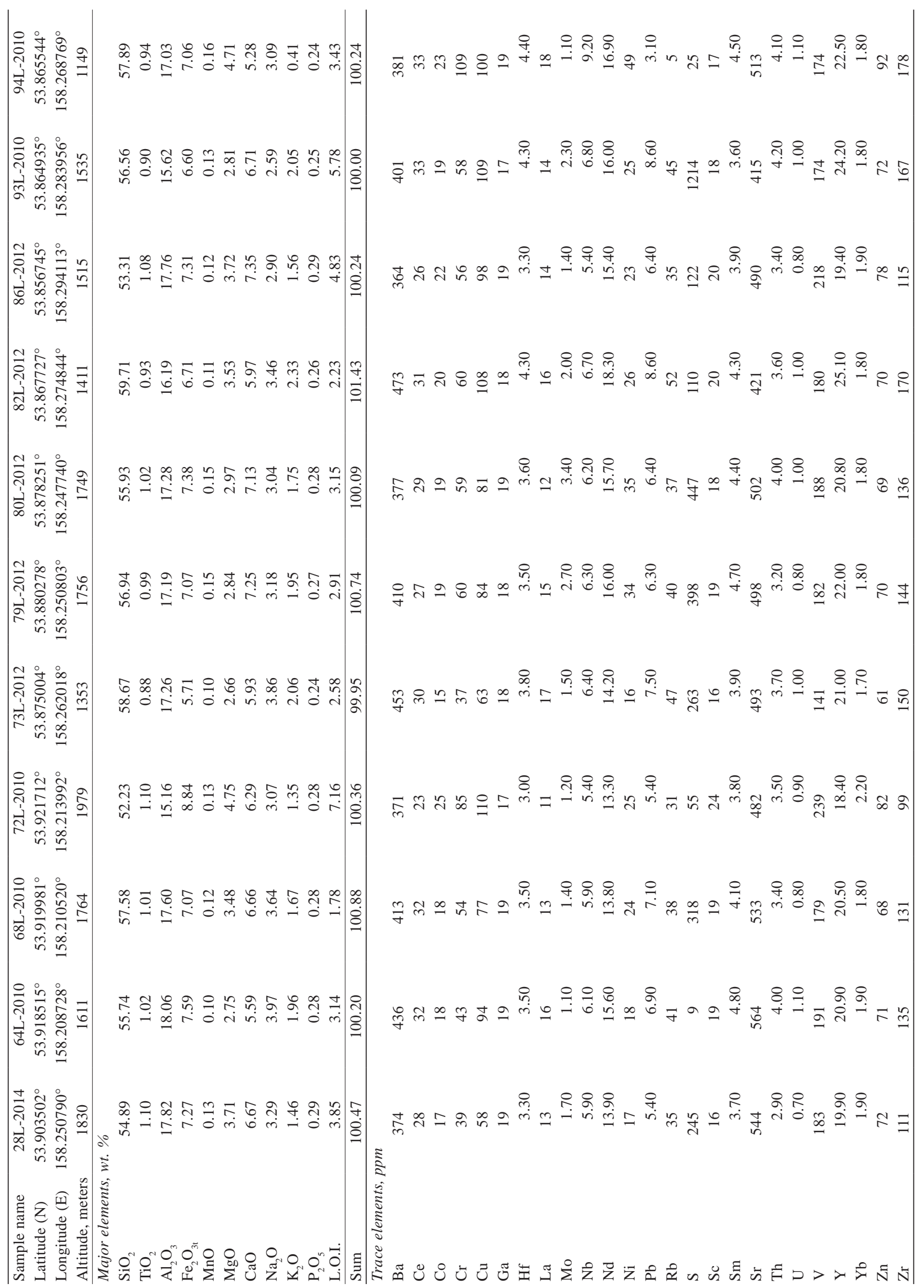




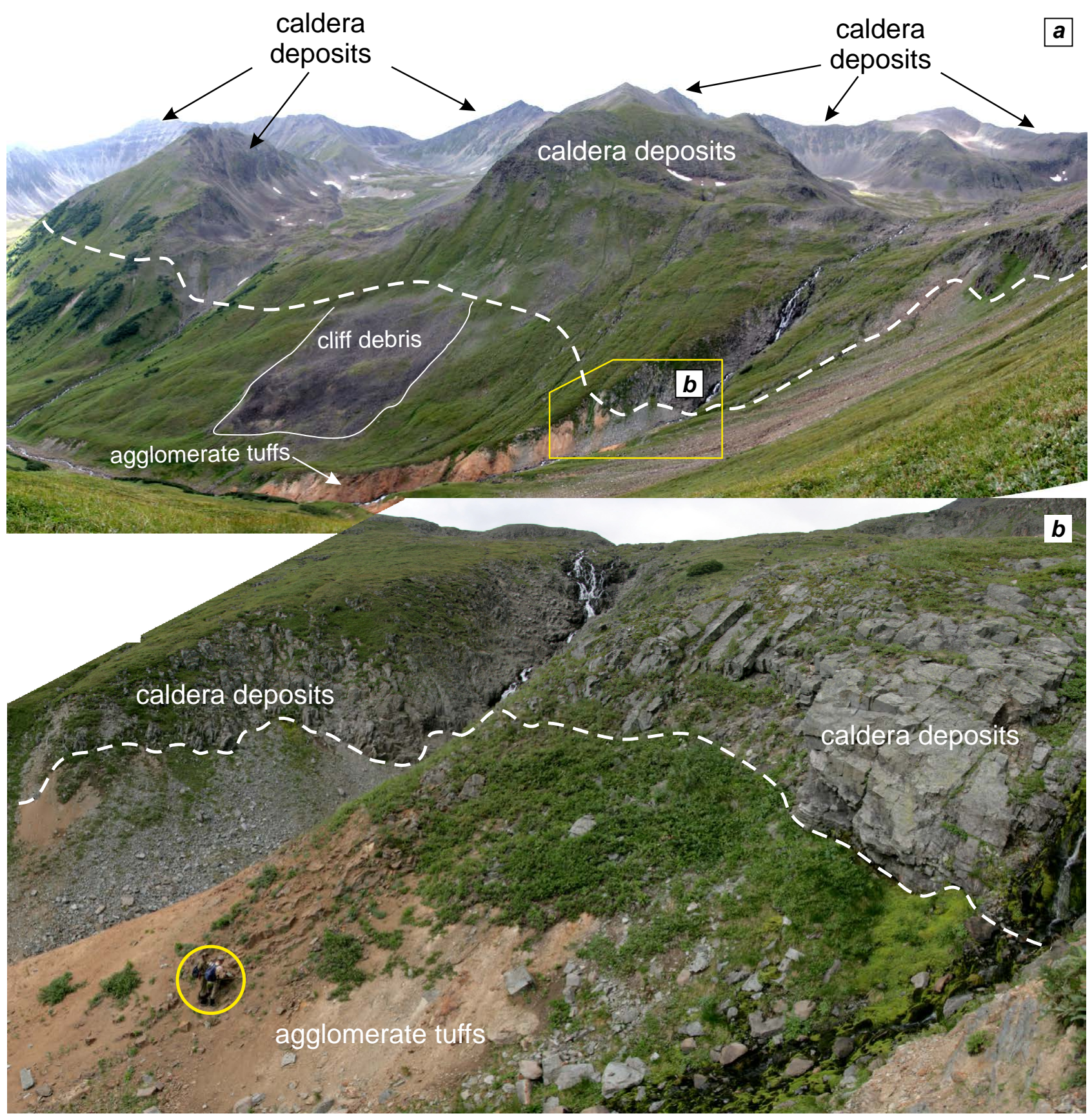

Fig. 9 Contact between Miocene agglomerate tuffs of pre-caldera stage and ignimbrite layers from caldera-forming eruptions in outcrop at Pad' Glubokaya river. a - Entire outcrop. b - Zoomed photo of the contact, a person is circled for scale. Locations of outcrops are shown on Fig. 2.

$14 \mathrm{~km}$ from north to south (Fig. 2). Within the studied area, the deposits have nearly horizontal bedding and this makes possible to recognize boundaries over large

Tab. 4 U-Pb ages of zircon xenocrysts in sample 25L-2009

\begin{tabular}{lccccc}
\hline & ${ }^{207}$ corrected ${ }^{206} \mathrm{~Pb} /{ }^{238} \mathrm{U}$ age, Ma & $1 \sigma$ & \% radiogenic & Th, ppm & $\mathrm{U}, \mathrm{ppm}$ \\
\hline 25L_z_1 & 79.0 & 2.6 & 96.3 & 28 & 140 \\
25L_z_4 & 80.4 & 2.3 & 98.4 & 38 & 135 \\
25L_z_2 & 82.0 & 2.1 & 99.2 & 44 & 171 \\
\hline
\end{tabular}

distances. We determine intra-caldera deposits based on alternating layers of ignimbrites and volcaniclastic deposits. The thickness of outcropping successions of interbedded layers exceeds 500 meters inside the caldera. In the northern part the volcanogenic layers dip $10-12^{\circ}$, while in the eastern part their dip decreases to $5-6^{\circ}$ (Fig. 2). We suggest that asymmetric distribution of 


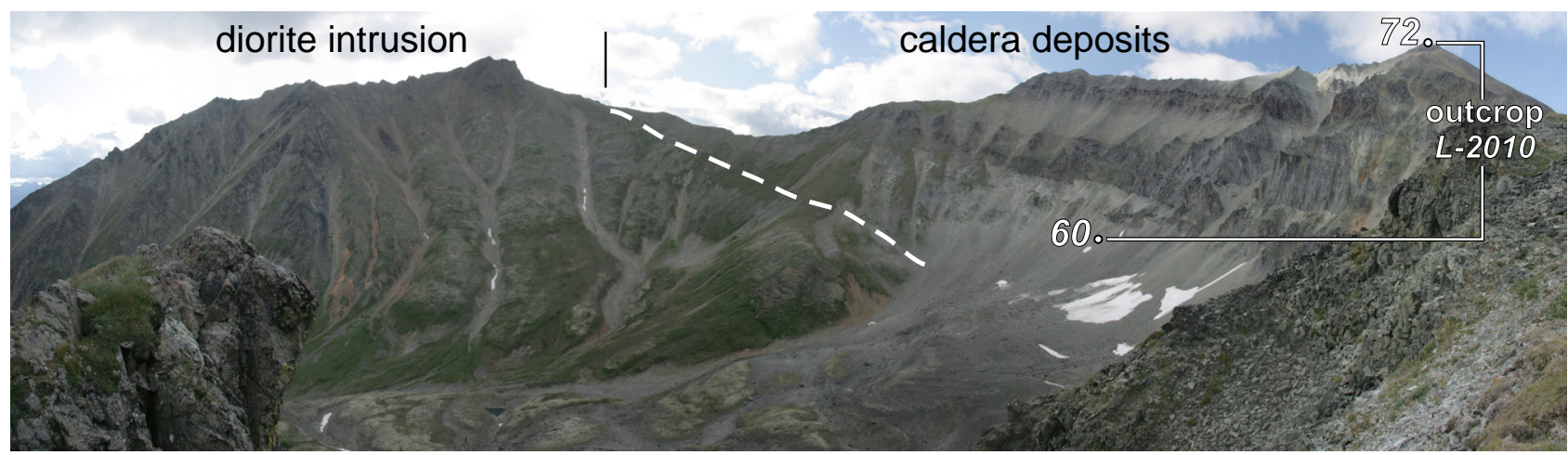

Fig. 10 Contact between the volcano-sedimentary rocks of caldera stage and post-caldera diorite intrusion. Location is shown on Fig. 2.

ignimbrites reflects movements along the regional faults. We conclude that this newly described boundary of paleovolcano currently has tectonic boundaries in the north-east, because regional fault distorted primary bedding of the layers and dips of the layers increase in this direction (Fig. 2). All other boundaries are just naturally eroded sections with decreasing thicknesses of the layers towards the margin of the edifice.

Surviving extra-caldera deposits are distributed over a large area of the EVB (Fig. 1) with individual pyroclastic layers significantly thinner than in intra-caldera deposits as the exposed thickness does not exceed several meters. One of the representative outcrops of the extracaldera deposits is Mt. Stol, located $50 \mathrm{~km}$ NNE of the VC (Fig. 1). The Ar-Ar age of Mt. Stol is $3.71 \pm 0.08$ Ma (Leonov et al. 2008), younger than VC, but it also consists of mafic ignimbrites with 56-57 wt. $\% \mathrm{SiO}_{2}$ (Bindeman et al. 2010). Paleomagnetic data from ignimbrites from Mt. Stol have the same characteristics as ignimbrites from Karymsky and Shymnyi creeks, in the basin of the Levaya Zhupanova and Pravaya Zhupanova rivers (Fig. 1) (Shantser and Kraevaya 1980). Outcrops on Mt. Stol show regular continuous changes in environmental conditions from submarine continental slope with agglomerates, boulders, pebbles to subaerial volcanism with ignimbrites and lava flows (Bergal-Kuvikas et al. 2019). Towards the top of the outcrops, ignimbrite layers are interspersed with conglomerates, which can be interpreted as reflecting a period of intense denudation by water between caldera-forming eruptions.

\subsection{Relations of pyroclastic deposits with older (pre-caldera stage) and younger (post-caldera stage) rocks}

The pyroclastic rocks rest on the Miocene porphyritic basalts, agglomerate tuffs, as well as Late Cretaceous siltstones and argillites (Shantser and Kraevaya 1980; Sheimovich and Markovsky 2000) (Fig. 2). Outcrops with contact between the pyroclastic deposits and agglomerates are located in the western part of the Avachinsky Range, along the Pad' Glubokaya river (Fig. 9). Not surprisingly, the only a few zircons that could have been recovered from the ignimbrites are Cretaceous xenocrysts (Tab. 4).

Due to active uplift of the area (Nikolaev 1977), Avacha river graben formation, arc-perpendicular and other tectonic forces, primary bedding in studied area is disturbed more than $1.5 \mathrm{~km}$ away from the fault areas. Additionally, during the Avacha river graben formation, the Pliocene or younger sheets and extrusive domes were emplaced over the pyroclastic deposits (Legler 1976) (Figs 2, 10). Monogenetic volcanism with numerous cinder cones associated with displacement of regional faults was active in Late Pleistocene-Holocene times (Dirksen and Melekestsev 1999).

\section{Discussion}

\subsection{Determining the type of the Verkhneavachinsky paleovolcano}

Based on data presented so far, we interpret the Verkhneavachinsky paleovolcano (Fig. 1) as a shield paleovolcano with a summit caldera using the following arguments: (1) widespread distribution of the calderaproduced deposits; (2) continuous basaltic-andesitic ignimbrite layers without breaks covering almost the whole area; (3) sub-horizontal bedding of ignimbrites and volcaniclastic deposits suggestive that the slopes of the volcano were not steep as on stratovolcanoes. Instead they resembled the gentle slopes of a caldera with a wide crater, like on shield volcanoes.

Minimal volume of erupted pyroclastic deposits and the scale of the newly defined caldera are possible to estimate using the correlation of the dense rock equivalent (DRE) and the caldera area (Mason et al. 2004). We assume that paleocaldera has a circular form of intra-caldera deposits with a minimum diameter of $\sim 10$ $\mathrm{km}$. The area of this circle was calculated as $78.5 \mathrm{~km}^{2}$ $\left(\mathrm{S}=\pi \mathrm{r}^{2}\right)$. Intersection of the calculated area of the caldera and DRE gives us $\sim 220-230 \mathrm{~km}^{3}$ of pyroclastic deposits 


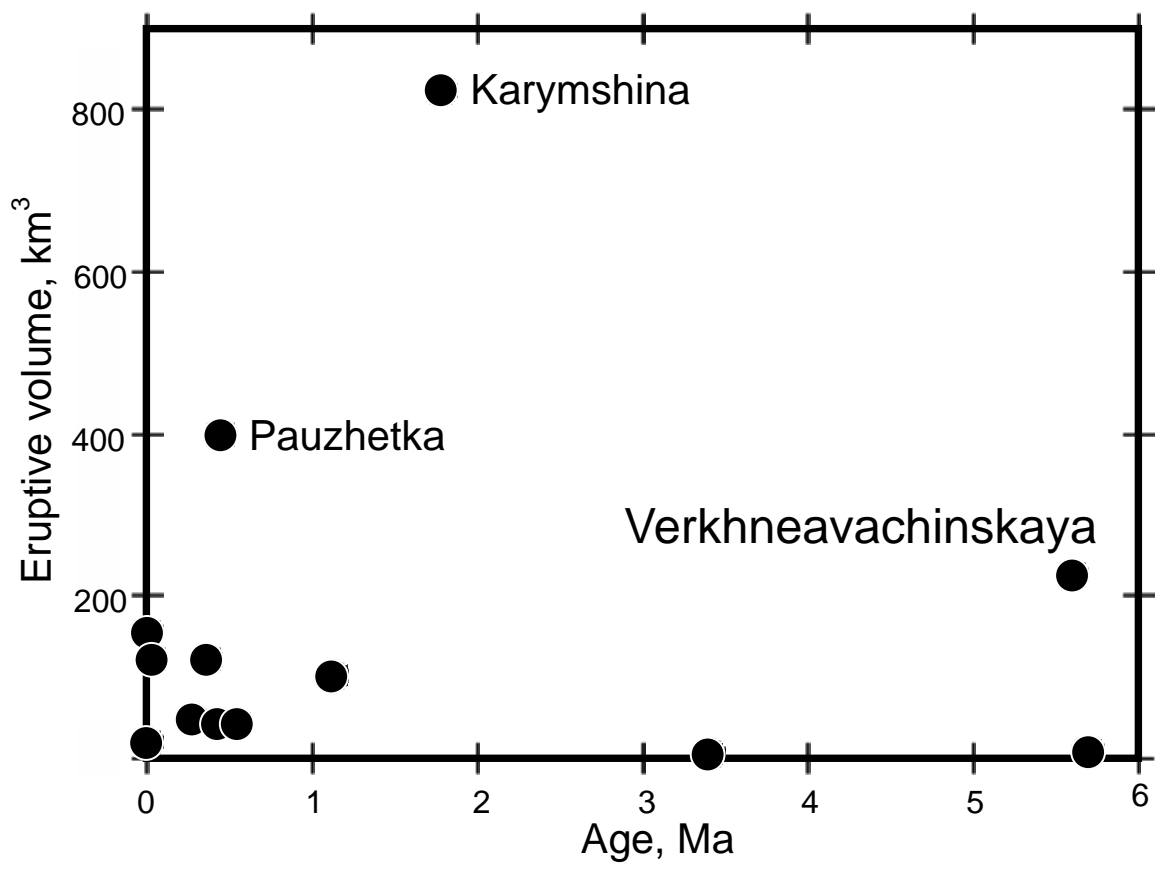

Fig. 11 Comparing scales and sizes of VC with other Kamchatkan calderas, using data from Bindeman et al. (2010).
(Leonov et al. 2011). Using the collapse caldera criteria of Lipman (2000), we define the VC as a large shield caldera. Compared with other known large volcanoes and calderas of Kamchatka (Bindeman et al. 2010), the VC is one of the oldest and largest presently known morphologically preserved calderas (Fig. 11).

Continuous, massive ignimbrite layers cover significant area around the VC. The distribution of the VC pyroclastic deposits and ignimbrites centered at the VC means that the eruptions were generated from a single vent and the pyroclastic flows were energetic enough. This was likely because they were enriched in gases and had high temperatures, allowing a transport over long distances from their source. Such an interpretation is consistent with Henry and Wolff's (1992) idea that caldera-generated boil-over lava-like ignimbrites form thin layers (up to a few meters thick) in their distal portions. In case of VC, the basaltic-intermediate ignimbrites cover a wide area in southern part of the EVB. Commonly, basaltic andesites coexist with basaltic trachyandesites on VC (Fig. 8).

Experiments for gases extracted during fusion of alkali volcanic glasses substantiate that higher $\mathrm{CO}_{2}+\mathrm{SO}_{2}$ contents, with relatively smaller proportions of $\mathrm{H}_{2} \mathrm{O}$, are released than in calc-alkaline volcanic glasses (Bailey and Hampton 1990). This means that alkalis should be regarded as mobile elements in magma, forming gasenriched melts with potentially high explosive potential.

The original VC caldera ring-fault is not preserved due to erosion and significant uplift of the area (Leonov et al. 2011). For this reason, it is difficult to reconstruct the type of the pre-existing volcanic structure and classify its type (a single collapse caldera, a large shield volcano with overlapping caldera or any of the more complex types). It is well known that in many basaltic volcanoes, such as Hawaii, later eruptions flood and burry the preexisting calderas. Additionally, in areas with significant glacial erosion and subglacial eruptions, such as in eroded Icelandic volcanoes, caldera's walls are commonly impossible to trace precisely as these are obscured by faulting and post-caldera intrusions (e.g. Gudmundsson 1998; Browning and Gudmundsson 2015). Only the oblique displacement of eroded pyroclastic materials could be helpful to determine the type of paleovolcano as a shield caldera. Summarizing the above-listed arguments, we propose that the Verkhneavachinsky paleovolcano was a voluminous shield volcano with a collapse caldera on the top.

\subsection{Origin of pyroclastic and volcaniclastic deposits}

There is a reason why ignimbrites and welded tuffs worldwide are predominantly of more silicic composition than the VC. Upon eruption, the rapid quenching of pyroclastic fragments causes them to cool below the glass transition temperature (Tg), thus preventing their welding and flow upon compaction (Dingwell and Webb 1990; Freundt 1998). Studies of 389 natural hydrous melts suggested that $\mathrm{Tg}$ is (1) strongly reduced with increasing water content and (2) dependent on cooling history (Hess and Dingwell 1996; Giordano et al. 2005). As both these temperatures are lower for silicic magmas, and water contents are typically higher, welding occurs predominantly in more silicic rocks. In order to make mafic pyroclastic material to weld, the eruption must be 
fast enough to maintain a temperature above $\mathrm{Tg}$, and have also enough water to be pyroclastic (and not effusive) and also to aid welding. A fast eruption may occur in response to the massive evacuation from a caldera.

Observed columnar jointing of the VC ignimbrite facies implies a high emplacement temperature, as the magma was hot enough to deform and stretch vesiculated glasses and form glassy fiamme. Welded, hyalopilitic, or eutaxitic textures of the ignimbrites suggest that pyroclastic flows were hot when ignimbrites were emplaced because ash and scoria fragments were still plastic and malleable. Plagioclase microcrysts formed before and during the eruption in the moving flows, as they became oriented according to pyroclastic flows directions. Experimental data from Ryan and Sammis (1981) show that the $\mathrm{Tg}$ of basaltic glass is $725^{\circ} \mathrm{C}$, and partial melting (thus clast welding) occurs at $\mathrm{T}>980^{\circ} \mathrm{C}$, suggesting that the emplacement temperature for VC rocks was in between 725 and $980^{\circ} \mathrm{C}$. Considering that Holocene Kamchatkan basalts, like many other basalts worldwide, commonly erupt at $\sim 1250-1270^{\circ} \mathrm{C}$ when drawn from thick continental arcs (Bergal-Kuvikas et al. 2017), the temperature interval between eruption and cooling is adequate for welding to occur should the right eruption conditions be maintained.

The reason why VC magmas erupted as pyroclastic ignimbrites and not lavas or occasional agglutinates is likely related to higher concentrations of volatiles and their behavior during magma degassing. Considering that $\mathrm{VC}$ has higher alkali contents in mafic magmas, the formation of gas-enriched pyroclastic flows was likely. Additionally, peculiarities of the Kamchatkan subduction zone result in one of the largest variations of volatiles in island-arc basalts. For example, Holocene Klyuchevskoy volcano yielded up to $7 \mathrm{wt}$. $\% \mathrm{H}_{2} \mathrm{O}$ variations in basalts (Auer et al. 2009). It can be assumed that contents of volatiles at initial stage of EVB during the Miocene were much larger, because thickness of the crust was minimal. This could explain why basaltic andesitic magmas were so explosive.

High-grade mafic ignimbrites are formed when pyroclastic flows remain well above the minimum welding temperature during their transport and deposition. High temperatures correspond to low magma viscosities, enabling particle coalescence and deformation to form a deposit that appears lava-like (Freundt and Schmincke 1995). The presence of water, and generally more alkalirich compositions (often also F- and Cl-rich), should help in lowering the glass transition and solidus temperatures and thus enable welding. On the other hand, the column joints of ignimbrites developed in response to contraction during long-term cooling and colonnade orientations define cooling surfaces, and thus also directions of primary emplacement. The absence of gradation in pyroclastic material and its density variations (with the densest material at the bottom and ash at the top of ignimbrite) (Fig. 5) testifies to the fast welding of chaotically emplaced flow deposits of the ignimbrites, without fountaining of vertical eruption column sorting (Sparks et al. 1973). However, the mechanism forming the observed thin (several meters in thickness) welded ignimbrites remains an open question. We believe that these reflect mainly (1) high temperatures of pyroclastic flows, (2) relatively alkali-rich basaltic melts, capable of producing volatile-enriched magmas and at least (3) volatiles-driven degrease in Tg, enabling formation of ignimbrites with basaltic-andesitic compositions.

Volcaniclastic deposits are widely distributed on all outcrops. They are continuously interbedded with ignimbrite layers across all intra-caldera deposits (Fig. 2). This means that the processes forming pyroclastic and volcaniclastic deposits were pulsatory and acted repeatedly one after another during the entire volcano formation. Stratigraphic records of interbedded layers of volcaniclastic deposits and ignimbrites testify for their joint genesis or syn-eruptive sediment accumulation and ignimbrite formation. Syn-eruptive volcanogenic accumulation means immediate or subsequent reworking and accumulation of pyroclastic deposits by surface processes, including wearing and erosion (Manville et al. 2009). Volcanogenic facies is composed of texturally unmodified clasts, compositionally identical to the surrounding ignimbrite layers. The clasts were thus autoclasts sensu McPhie (1993). These volcaniclastic deposits are primarily made of particles generated by in situ, non-explosive fragmentation. Cemented, non-welded matrix-supported volcaniclastic deposits with rounded clasts of ignimbrites suggest for transportation by water-saturated flows. Clear, sharp boundaries between lithofacies indicate distinct processes of formation and accumulation. Thus, one of the possible genetic models for the VC assumes continuous, long-term eruptions of hot pyroclastic flows (that generated the ignimbrites) and post-eruption volcaniclastic deposits accumulation (e.g. formation of lahars).

Observed differences in volcaniclastic deposits, e.g. existence or absence of the clasts, as well as variations in pyroclastic density currents, enable us to discuss the origin of vertical zonation in volcaniclastic deposits. Lower parts of natural outcrops, represented by cemented, non-welded tuffs with various sizes of the clasts (Fig. 6d), record beginning of the volcano formation. In opposite, upper parts of outcrops are observed fine tuffs without any clasts inside (Fig. 6c). Possible explanation of observed vertical zonation is progressive growth of a volcanic edifice during the time. Studies of eroded volcanoes suggested that there are some tendencies of changes in dense pyroclastic currents from the source of eruptions to the growing stage of the volcano (Manville 


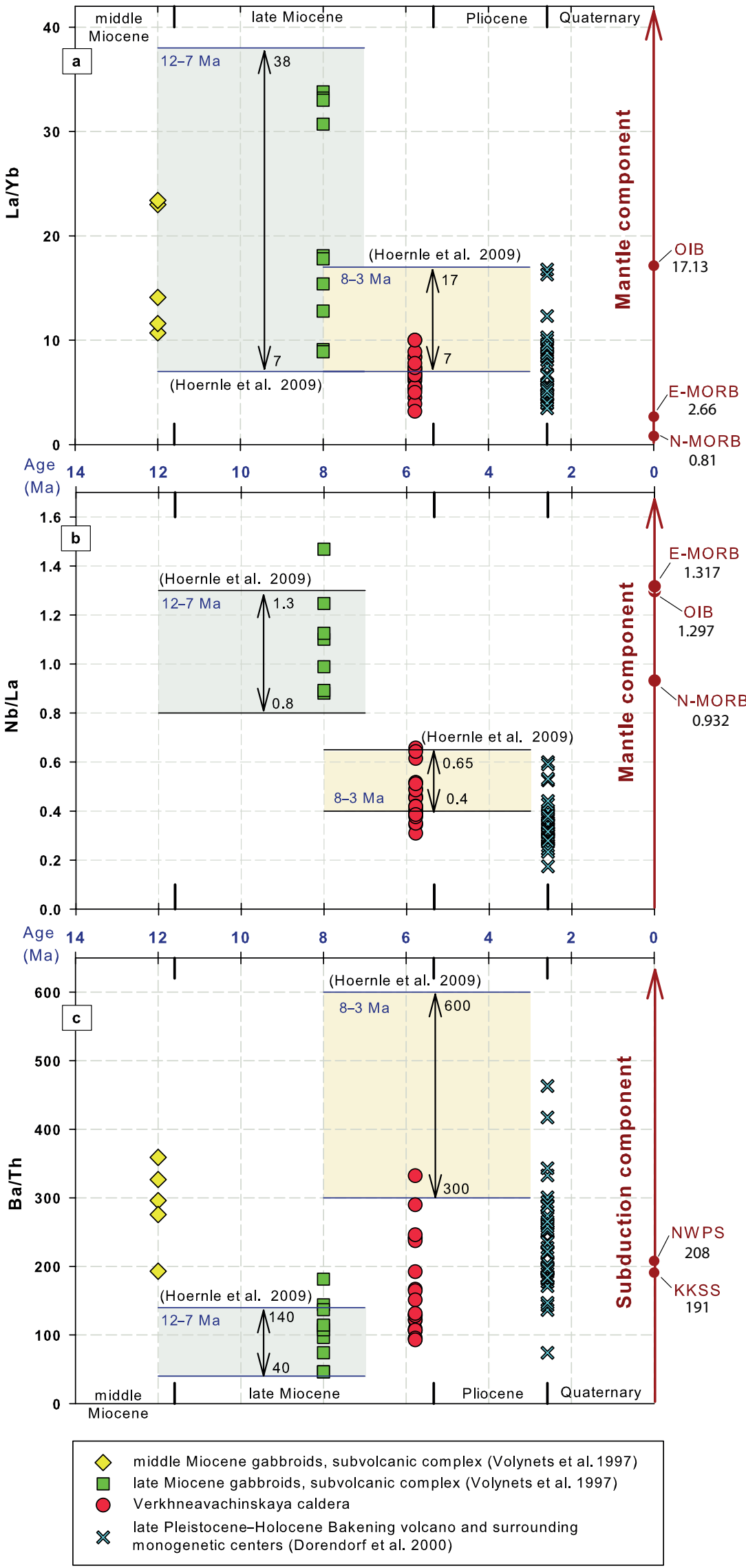

et al. 2009). At initial stage of volcano formation, close to the vent formed some massive rocks (e.g. lava flows, autoclastic and pyroclastic breccias and hypabyssal intrusions) and then pyroclastic materials pass laterally into medial apron associations (e.g. pyroclastic-flow, debris-avalanche, debris- and hyperconcentrated flow (lahar) deposits). Finally developed the association of braided to meandering fine, thin materials (e.g. fluvial system deposits, overbank alluvium, and interbedded tephras) (Manville et al. 2009).

\subsection{Contribution of the newly identified Verkhneavachinskaya caldera to understanding the geodynamic setting of Kamchatka}

The newly identified and reconstructed VC, with voluminous welded basaltic-andesitic ignimbrites, opens many questions about origin and evolution of magmatism in the central Kamchatka and also in similar environments worldwide. The genesis of such highly unusual mafic ignimbrites is likely related to specific conditions during magma genesis and eruptions (Robin et al. 1995; De Rita et al. 2002; Lohmar et al. 2010). The basement of the EVB contains two larger basaltic lava fields (along the Levaya Zhupanova river and on Tumrok Mt.) that were described by Shantser and Kraevaya (1980) (Fig. 4). The origin and geodynamic position of these lava fields are still discussed.

Comparison with other volcanic arcs, especially the Cascades in the western USA, helps to better understand the possible source of basaltic magmatism flare-ups in Kamchatka. Cascadia Arc is one of the active vol-

Fig. 12. Variations of fluid-immobile $(\mathrm{La} / \mathrm{Yb}$, $\mathrm{Nb} / \mathrm{La}$ ) and fluid-mobile $(\mathrm{Ba} / \mathrm{Th})$ ratios in EVB magmatic rocks of various ages. Compositions of OIB, E-MORB, and N-MORB are after Sun and McDonough (1989). Abbreviations: NWPS - north-west Pacific sediments, KKSS - Kamchatkan subducted sediment column according to Duggen et al. (2007). 
canic arcs that were formed due to Siletzia Terrane accretion to the North American Continent between 50.5 and $45 \mathrm{Ma}$ (Wells et al. 2014). This accretion produced voluminous basaltic eruptions with OIB signature, perhaps due to delamination and associated decompression melting of previously hydrated lower crust (Wells et al. 2014). In the case of Eastern Kamchatka, the accretion of Kronotsky Arc took place between 15 and $2 \mathrm{Ma}$ (Lander and Shapiro 2007; Avdeiko and Bergal-Kuvikas 2015) and delamination could have similarly generated basaltic lava fields with OIB and adakitic signatures limited in time and space.

It was previously found for the central segment of EVB that the rocks in this region can be divided into two main groups of different age and chemical composition (Volynets et al. 1997, Hoernle et al. 2009). One group of basalts with age of 7-12 Ma was formed before the Kronotsky Arc accretion and is represented by OIB-like alkaline and transitional basalts with $\mathrm{La} / \mathrm{Yb}=7-38, \mathrm{Nb} /$ $\mathrm{La}=0.8-1.3$, and $\mathrm{Ba} / \mathrm{Th}=40-140$. Overlying second group of rocks with age 3-8 Ma was formed after the accretion and is represented by andesites and dacites with some adakite component and the following trace-element ratios: $\mathrm{La} / \mathrm{Yb}=7-17, \mathrm{Sr} / \mathrm{Y}=53-68, \mathrm{Nb} / \mathrm{La}=0.40-0.65$, $\mathrm{Ba} / \mathrm{Th}=300-600$ (Hoernle et al. 2009).

On the contrary, Shanster and Kraevaya (1980) suggested that faults and fissures, generated on a continental slope during the early stage of EVB formation in Miocene, were responsible for production of areally extensive volcanism on Tumrok Mt. and on Levaya Avacha river.

Some trace-element ratios of the VC and Mt. Stol ignimbrites (50.7-59.7 wt.\% $\mathrm{SiO}_{2}, 3.71 \pm 0.08 \mathrm{Ma}$ - Leonov et al. 2008), presumably formed after the Kronotsky Arc Terrane accretion at 5.78-3.71 Ma, resemble the younger group $(\mathrm{La} / \mathrm{Yb}=3.2-10, \mathrm{Nb} / \mathrm{La}=$ 0.31-0.66). At the same time, other trace-element ratios $(\mathrm{Sr} / \mathrm{Y}=17-61, \mathrm{Ba} / \mathrm{Th}=93-332)$ show overlap between the two groups (Fig. 12). These data have two possible interpretations: (1) VC tapped a mixed mantle source during transition from an old to a newly formed subduction zone under EVB or (2) following the Kronotsky Arc Terrane accretion, the erupted rocks had much larger chemical variations than previously expected in the studied area. More geochemical and isotope data are needed to answer this question.

According to Shantser and Kraevaya (1980), fields of basaltic-andesitic ignimbrites were found only in the basement of the EVB. Later, the composition of magmatic suites changed into a more continuous, calc-alkaline magmatic series with silicic ignimbrites and lava flows typical of arcs. Considering the Kronotsky Terrane accretion with the spatially and temporally limited basaltic inputs into the EVB, we suggest that voluminous, predominantly basic ignimbrites possibly formed soon after a subduction jump, during delamination and re-initiation of subduction in a new subduction zone (Fig. 12).

\section{Conclusions}

- Verkhneavachinskaya caldera is a Late Miocene (5.78-5.58 Ma, Ar-Ar age) basaltic caldera, one of the oldest and the largest morphologically-preserved calderas $(10 \times 12 \mathrm{~km})$ in Kamchatka.

- From global perspective, Verkhneavachinskaya caldera has rather unusual basaltic andesite to andesite compositions of its ignimbrites.

- The described pyroclastic deposits are interpreted as important indicators for understanding geodynamic setting of Kamchatka Arc after Kronotsky Arc Terrane accretion and re-initiation of subduction zone or subduction jump in this area of Kamchatka. It was perhaps accompanied by delamination during initial stage of subduction zone formation.

Acknowledgments. We are grateful to J. Martí, K. Nemeth and anonymous reviewers for providing thoughtful recommendations that led to significant improvements to the paper, as well as to V. Rapprich and V. Janoušek for editorial handling. Thanks are due to D. Vakulenko, S. Morozov, and M. Davydova for help with fieldwork. We wish to express our gratitude to E. Grib for helping with analytical procedures and useful discussions, and B. Jicha for obtaining Ar-Ar ages for the rocks. We are grateful to G. Fabbro for help in improving the English of the manuscript. Fieldworks were supported by grant \#15-I-2-031, 16-1-1-010 from the Far Eastern Branch of Russian Academy of Science to V. Leonov, whole-rock measurements by RFBR-DFG grant \#16-55-12040 to T. Churikova. O. Bergal-Kuvikas and I. Bindeman are grateful for support of the Russian Science Foundation grant \#19-17-00241.

\section{References}

Aliskerov A A (1980) Mineralization of shallow magmatism (Avachinsko-Ketkhoiskoy upwelling zone). Nauka, Moscow, pp 1-94 (in Russian)

Aprelkov SA, Popruzhenko SV, Bulanova AB (2005) Miocene-Quaternary volcanic center (paleovolcano) in Eastern Kamchatka. Lithosphere 3: 59-166 (in Russian)

AvdeiKo GP, BergaL-KuviKas OV (2015) The geodynamic conditions for the generation of adakites and Nb-rich basalts (NEAB) in Kamchatka. J Volcanol Seismolog 9: 295-306

Avdeiko GP, Savelyev DP, Palueva AA, Popruzhenko SV (2007) Evolution of the Kurile-Kamchatkan vol- 
canic arcs and dynamics of the Kamchatka-Aleutian junction. In: Eichelberger J, Gordeev E, Izbekov P, Kasahara M, Lees J (eds) Volcanism and Subduction: The Kamchatka Region. Geophysical Monograph Series 172: 37-55

Auer S, Bindeman I, Wallace P, Ponomareva V, PortNYAGIN M (2009) The origin of hydrous, high- $\delta^{18} \mathrm{O}$ voluminous volcanism: diverse oxygen isotope values and high magmatic water contents within the volcanic record of Klyuchevskoy volcano, Kamchatka, Russia. Contrib Mineral Petrol 157: 209

Bailey DK, Hampton CM (1990) Volatiles in alkaline magmatism. Lithos 26: 157-165

Bergal-Kuvikas OV, LeONOV VL, Rogozin AN, BindeMAN IN, KLIAPITSKIY ES (2016a) Correlation of ignimbrite deposits from Verkhneavachinskaya caldera (Eastern Range, Kamchatka). In: Kogarko LN (ed) Moscow International School of Earth Sciences 2016. Vernadsky Institute of Geochemistry and Analytical Chemistry RAS, Vernadsky State Geological Museum RAS, Lomonosov Moscow State University, Moscow, pp 31

Bergal-KuviKas OV, Leonov VN, Rogozin AN, BindeMAN IN, KLYUPITSKIY ES (2016b) New discovered Late Miocene Verkhneavachinskaya caldera on Eastern Kamchatka. In: Freymueller J, IZBeKov P, EICHELberger J (eds) $9^{\text {th }}$ Biennial Workshop on Japan-KamchatkaAlaska Subduction Processes (JKASP-2016). Alaska University, Fairbanks, pp 52-53

Bergal-Kuvikas OV, NaKagawa M, Kuritani T, Muravyev Y, Malik N, KlimenKo E, Amma-Miyasaka M, Matsumoto A, Shimada S (2017) A petrological and geochemical study on time-series samples from Klyuchevskoy volcano, Kamchatka Arc. Contrib Mineral Petrol 172: 35-51

Bergal-Kuvikas OV, Rogozin AN, Klyapitsky ES (2019) The analysis of spatial distributions, origins of caldera-forming eruptions with basaltic-andesitic magma compositions, and genesis of Miocene ignimbrites of the Eastern Volcanic Belt, Kamchatka. Geodynamics and Tectonophysics 10: 815-828 (in Russian)

Bindeman IN, Leonov V L, Izbekov PE, Ponomareva VC, Watts KE, Shipley NK, Schmitt AK (2010) Largevolume silicic volcanism in Kamchatka: Ar-Ar and U-Pb ages, isotopic, and geochemical characteristics of major pre-Holocene caldera-forming eruptions. J Volcanol Geotherm Res 189: 57-80

Bindeman IN, Anikin AP, Schmitt AK (2016) Archean xenocrysts in modern volcanic rocks from Kamchatka - insight into the basement and paleodrainage. J Geol 124: 247-253

Bindeman IN, Leonov VL, Colón DP, Rogozin AN, Shipley N, Jicha B, GerYa TV (2019) Isotopic and petrologic investigation, and a thermomechanical model of genesis of large-volume rhyolites in arc environ- ments: Karymshina Volcanic Complex, Kamchatka, Russia. Front Earth Sci 6: 238

Bogdanovich K (1904) Geologische Skizze von Kamtschatka. Peterm Geogr Mitt 3: 24-25

Boyarinova ME, Veshnyakov NA, Korkin AG, SAVElyev DP, Litvinov AA (2006) State Geological Map of Russian Federation. Scale 1:200 000. Map Sheets N-57-XII, XVIII, N-58-VII. VSEGEI. Sankt-Petersburg (in Russian)

BRowning J, Gudmundsson A (2015) Caldera faults capture and deflect inclined sheets: an alternative mechanism of ring dike formation. Bull Volcanol 77: 4

Churikova T, Dorendorf F, Wörner G (2001) Sources and fluids in the mantle wedge below Kamchatka, evidence from across-arc geochemical variation. J Petrol 42: 1567-1593

De Rita D, Giordano G, Esposito A, Fabbri M, Rodani S (2002) Large volume phreatomagmatic ignimbrites from the Colli Albani volcano (Middle Pleistocene, Italy). J Volcanol Geotherm Res 118: 77-98

Dingwell DB, WebB SL (1990) Relaxation in silicate melts. Eur J Mineral 1990: 427-449

Dirksen OV, Melekestsev IV (1999) Chronology, evolution and morphology of plateau basalt eruptive centers in Avacha River area, Kamchatka, Russia. J Volcanol Seismolog 21: 1-27

Dorendorf F, Churikova T, Koloskov A, Wörner G (2000) Late Pleistocene to Holocene activity at Bakening volcano and surrounding monogenetic centers (Kamchatka): volcanic geology and geochemical evolution. J Volcanol Geotherm Res 104: 131-151

Duggen S, Portnyagin M, Baker J, Ulfbeck D, HoERNLE K, GARBE-SchöNBERG D, GRASSINEAU N (2007) Drastic shift in lava geochemistry in the volcanic-front to rear-arc region of the Southern Kamchatkan subduction zone: evidence for the transition from slab surface dehydration to sediment melting. Geochim Cosmochim Acta 71: 452-480

EGOROV ON (2009) Structure formations and magmagenesis over upper mantle plume in volcanic belt in transition zone between ocean-continents. In: NASURENKo Yu (eds) Centers of Inner Activities. Schmidt Institute of Physics of the Earth, Moscow, pp 1-297 (in Russian)

FisHeR RV (1961) Proposed classification of volcaniclastic sediments and rocks. Geol Soc Am Bull 72: 1409-1414

FREUNDT A(1998) The formation of high-grade ignimbrites, I: experiments on high-and low-concentration transport systems containing sticky particles. Bull Volcanol 59: 414-435

Freundt A, Schmincke HU (1995) Eruption and emplacement of a basaltic welded ignimbrite during caldera formation on Gran Canaria. Bull Volcanol 56: 640-659

Geist EL, Scholl DW (1994) Large-scale deformation related to the collision of the Aleutian Arc with Kamchatka. Tectonics 13: 538-560 
Giordano D, Nichols AR, Dingwell DB (2005) Glass transition temperatures of natural hydrous melts: a relationship with shear viscosity and implications for the welding process. J Volcanol Geotherm Res 142: 105-118

Global Volcanism Program (2013) Volcanoes of the World, V.4.8.4. In: VenZKe E (ed). Smithsonian Institution. Downloaded on 25 December 2019 from https://doi. org/10.5479/si.GVP.VOTW4-2013

Gudmundsson A (1998) Formation and development of normal-fault calderas and the initiation of large explosive eruptions. Bull Volcanol 60: 160-170

HENRY CD, JA WoLfF (1992) Distinguishing strongly rheomorphic tuffs from extensive silicic lavas. Bull Volcanol 54: 171-186

Hess KU, Dingwell DB (1996) Viscosities of hydrous leucogranitic melts: a non-Arrhenian model. Amer Miner 81: 1297-1300

Hoernle KA, Portnyagin MV, Hauff F, van den BoGAARD P, AvDEIKo G (2009) The origin of EM1 alkaline magmas during Cenozoic reorganization of subduction zone of Kamchatka. Geochim Cosmochim Acta Suppl 73: A538

Hourigan JK, Brandon MT, Soloviev, AV, Kirmasov AB, Garver JI, Stevenson J, Reiners PW (2009) Eocene arc-continent collision and crustal consolidation in Kamchatka, Russian Far East. Amer J Sci 309: 333-396

Hughes GR, MAhood GA (2008) Tectonic control on the nature of large silicic calderas in volcanic arcs. Geology 36: 627-630

KLIAPITSKIY ES (2014) New data of geochemistry of ignimbrites on Verkhneavachinskaya caldera. In: SeLIVERSTOV NI (ed) XIII Regional Scientific Conference for Young Scientists, 15 April 2014, Abstract Volume. Kamchatka State University and Institute of Volcanology and Seismology RAS, Petropavlovsk-Kamchatsky, pp 81-90 (in Russian)

KonstantinOvSKaYA E (2011) Early Eocene arc-continent collision in Kamchatka, Russia: structural evolution and geodynamic model. In: Brown D, RYAN PD (eds) ArcContinent Collision. Springer-Verlag, Berlin Heidelberg, pp 247-277

Kuiper KF, Deino A, Hilgen FJ, Krijgsman W, Renne PR, WiJBrans AJ (2008) Synchronizing rock clocks of Earth history. Science 320: 500-504

Kuvikas OV, Rogozin AN (2009) First results of 500 meters ignimbrite sections investigation (Kavycha river, Eastern Kamchatka). In: Seliverstov NI (ed) VII Regional Scientific Conference for Young Scientists, 25 November 2009. Kamchatka State University and Institute of Volcanology and Seismology RAS, PetropavlovskKamchatsky, pp 39-49 (in Russian)

LANDER AV, SHAPIRO MN (2007) The origin of the modern Kamchatka subduction zone. In: EICHELBERGER J, GoRdeev E, Izbekov P, Kasahara M, Lees J (eds) Volcanism and Subduction: the Kamchatka Region. Geophysical Monograph Series 172: 57-64

LEGLER VA (1976) Deformation of the subducting lithospheric plate and longitudinal shifts of the Kuril-Kamchatka island Arc. In: Sorohtin ON (ed) Tectonics of the Lithospheric Plates (Dynamics of the Subduction Zone). PP Shirshov Institute of Oceanology AN SSSR, Moscow, pp 103-147 (in Russian)

LeONOV VL, BINDEMAN IN, Rogozin AN (2008) New ArAr dating of Kamchatkan ignimbrites. In: GoRDEEv EI (ed) Conference for Volcanologist Day, Abstract Volume. Institute of Volcanology and Seismology, PetropavlovskKamchatsky, pp 187-197 (in Russian)

Leonov VL, Rogozin AN, Bindeman IN, Kuvikas OV, KLYPITSKIY ES (2011) Determination new caldera on Kamchatka: boundary, age, complex of intra-caldera deposits, unsolved questions. In: GordeEv EI (ed) Conference for Volcanologist Day, Abstract Volume. Institute of Volcanology and Seismology, PetropavlovskKamchatsky, pp 53-56 (in Russian)

Le Maitre RW (ed) (2002) Igneous Rocks: a Classification and Glossary of Terms: Recommendations of the IUGS, Subcommission on the Systematics of Igneous Rocks. Cambridge University Press, Cambridge, pp $1-236$

LeVINA AP, LeIPShig AV, Lyubimova SV, Kustov YE (1983) Map of principal trends in paleotopography development on the USSR territory. Scale 1:10 000 000. In: SIDORENKo AV (ed) Paleomorphological Atlas. VSEGEI, Leningrad, pp 50-51 (in Russian)

LipMAn PW (2000) Calderas. In: Sigurdsson H (ed) Encyclopedia of Volcanoes. Academic Press, San Francisco, pp 643-662

Lohmar S, Robin C, Gourgaud A, Clavero J, Angel Parada M, Moreno H, Naranjo JA (2010) Evidence of magma-water interaction during the 13,800 years BP explosive cycle of the Licán ignimbrite, Villarrica volcano (southern Chile). Andean Geol 34: 233-248

Manville V, Németh K, Kano K (2009) Source to sink: a review of three decades of progress in the understanding of volcaniclastic processes, deposits, and hazards. Sediment Geol 220: 136-161

Mason BG, Pyle DM, Oppenheimer C (2004) The size and frequency of the largest explosive eruptions on Earth. Bull Volcanol 66: 735-748

McPhie J, Doyle M, Allen SR (1993) Volcanic Textures: a Guide to the Interpretation of Textures in Volcanic Rocks. Centre for Ore Deposit and Exploration Studies, University of Tasmania, Hobart, pp 1-198

Nikolaev NI (1977) Map of recent tectonic of USSR and adjacent area. VSEGEI, Leningrad (in Russian)

PIIP B (1941) Materials of geology and petrography in rivers of Avacha, Rassoshiny and Kavycha on Kamchatka. In: ZaVARITSKY A, VloDAVETS V (eds) Works of Kamchatkan 
Complex Expedition in 1936-1937. Nauka, Moscow Leningrad, pp 1-128 (in Russian)

Robin C, EISSEN JP, MonZIER M (1995) Mafic pyroclastic flows at Santa Maria (Gaua) volcano, Vanuatu: the caldera formation problem in mainly mafic island arc volcanoes. Terra Nova 7: 436-443

Rogozin AN, KLIAPITSKIY ES (2010) Geochemical characteristics of ignimbrites on headwaters of Avacha river (according to results of field works in 2009-2010). In: Seliverstov NI (ed) VIII Regional Scientific Conference for Young Scientists, 25 November 2009, Abstract Volume. Kamchatka State University and Institute of Volcanology and Seismology RAS, PetropavlovskKamchatsky, pp 29-39 (in Russian)

Rogozin AN, LeONOv VL, KuviKas OV (2011) Unusual ignimbrites of Verkhneavachinskaya caldera (Kamchatka): structure of natural sections, geochemical characteristics. In: Koroteev VA, Malush AI, VolcheK EN (eds) Volcanism and Geodynamics. Materials of V All Russian Symposium on Volcanology and Seismology. Institute of Geology and Geochemistry, Ekaterinburg, pp 234-237 (in Russian)

Ryan MP, SAMmis CG (1981) The glass transition in basalt. J Geophys Res: Solid Earth 86 B10: 9519-9535

Savelyev DP, Palechek TN, Portnyagin MV (2005) Campanian oceanic siliceous-volcanogenic deposit in the basement of the East Kamchatka volcanic belt. Rus J Pac Geol 24: 46-54 (in Russian)

Shantser AE, Kraevaya TS (1980) Formation Series of the Terrestrial Volcanic Belt (the Late Cenozoic of Kamchatka as an Example). Nauka, Moscow, pp 1-164 (in Russian)
Sheimovich VS, Markovsky VA (2000) Geological map of Russian Federation Scale 1:200 000. Issue Southern Kamchatka. Lists N-57-XXVII, N-57-XXXIII. Karpinsky Russian Geological Research Institute, Moscow, pp 1-302 (in Russian)

Sparks RSJ, Self S, Walker GP (1973) Products of ignimbrite eruptions. Geology 1: 115-118

Sun SS, McDonough WF (1989) Chemical and isotopic systematics of oceanic basalts: implications for mantle composition and processes. In: SAUnders A, NorRY M (eds) Magmatism in the Ocean Basins. Geological Society, London, Special Publications 42: 313-345

Volynets ON (1994) Geochemical types, petrology, and genesis of Late Cenozoic volcanic rocks from the Kurile-Kamchatka island-arc system. Int Geol Rev 36: 373-405

Volynets ON, Karpenko SF, Kehu RU, Gorring M (1997) Isotopic composition of Late Neogene K-Na alkaline basalts of eastern Kamchatka: indicators of the heterogeneity of the mantle magma sources. Geochem Int 35: 884-896

vON Ditmar C (1901) Visiting and residence in Kamchatka since 1851 to 1855. Part 1. Academy of Science, SanktPetersburg, pp 377-667 (in Russian)

Wells R, Bukry D, Friedman R, Pyle D, Duncan R, HaeUSSLER P, WoODEN J (2014) Geologic history of Siletzia, a large igneous province in the Oregon and Washington Coast Range: correlation to the geomagnetic polarity time scale and implications for a long-lived Yellowstone hotspot. Geosphere 10: 692-697 